\title{
Chemical composition of boundary layer aerosol over the Atlantic Ocean and at an Antarctic site
}

\author{
A. Virkkula ${ }^{1}$, K. Teinilä ${ }^{1}$, R. Hillamo ${ }^{1}$, V.-M. Kerminen ${ }^{1}$, S. Saarikoski ${ }^{1}$, M. Aurela ${ }^{1}$, J. Viidanoja ${ }^{2}$, J. Paatero ${ }^{1}$, \\ I. K. Koponen ${ }^{3}$, and M. Kulmala ${ }^{4}$ \\ ${ }^{1}$ Finnish Meteorological Institute, Erik Palménin aukio, 00560, Helsinki, Finland \\ ${ }^{2}$ Department Department of Chemistry, Laboratory of Analytical Chemistry,University of Helsinki, 00014 Helsinki, Finland \\ ${ }^{3}$ University of Copenhagen, Department of Chemistry, Universitetsparken 5, 2100 Copenhagen, Denmark \\ ${ }^{4}$ Department of Atmospheric Sciences, Aerosol and Environmental Physics Laboratory, University of Helsinki, 00014 \\ Helsinki, Finland
}

Received: 5 October 2005 - Published in Atmos. Chem. Phys. Discuss.: 10 January 2006

Revised: 2 June 2006 - Accepted: 16 June 2006 - Published: 21 August 2006

\begin{abstract}
Aerosol chemical composition was measured over the Atlantic Ocean in November-December 1999 and at the Finnish Antarctic research station Aboa in January 2000. The concentrations of all anthropogenic aerosol compounds decreased clearly from north to south. An anthropogenic influence was still evident in the middle of the tropical South Atlantic, background values were reached south of Cape Town. Chemical mass apportionment was calculated for high volume filter samples $\left(\mathrm{D}_{p}<3 \mu \mathrm{m}\right)$. North of the equator 70 $80 \%$ of the aerosol consisted of non-sea-salt species. The contribution of sea salt was $\sim 25 \%$ in the polluted latitudes, $>80 \%$ in the Southern Ocean, and $<10 \%$ at Aboa. The contribution of organic carbon was $>10 \%$ in most samples, also at Aboa. The correlation of biomass-burning-related aerosol components with ${ }^{210} \mathrm{~Pb}$ was very high compared with that between nss calcium and ${ }^{210} \mathrm{~Pb}$ which suggests that ${ }^{210} \mathrm{~Pb}$ is a better tracer for biomass burning than for Saharan dust. The ratio of the two clear tracers for biomass burning, nss potassium and oxalate, was different in European and in African samples, suggesting that this ratio could be used as an indicator of biomass burning type. The concentrations of continentrelated particles decreased exponentially with the distance from Africa. The shortest half-value distance, $\sim 100 \mathrm{~km}$, was for nss calcium. The half-value distance of particles that are mainly in the submicron particles was $\sim 700 \pm 200 \mathrm{~km}$. The MSA to nss sulfate ratio, R, increased faster than MSA concentration with decreasing anthropogenic influence, indicating that the $\mathrm{R}$ increase could largely be explained by the decrease of anthropogenic sulfate.
\end{abstract}

Correspondence to: A. Virkkula

(aki.virkkula@fmi.fi)

\section{Introduction}

Large amounts of man-made and natural aerosols are transported every year from the continents over the ocean (Lelieveld et al., 2001; Kaufman et al., 2002; Chiapello and Moulin, 2002). In the marine environment, these continentally-derived aerosols influence the climate forcing patterns by scattering and absorbing solar radiation and by modifying cloud properties (Ramanathan et al., 2001; Sekiguchi et al., 2003). Other potential effects caused by these aerosols include perturbations in tropospheric chemistry via different heterogenous pathways (Ravishankara, 1997; Seinfeld, 2000).

Over the Atlantic Ocean, the physical, chemical and optical character of aerosols have been measured in association with several short-term campaigns, e.g., TARFOX (Russell et al., 1999), ACE-2 (Raes et al., 2000), with cruises across the ocean (Van Dingenen et al., 1995; Davison et al., 1996; Bates et al., 2001; Quinn et al., 2001; Leck et al., 2002), with longterm monitoring programs (e.g. Prospero, 1999) and with satellite data (Bergstrom and Russell, 1999; Chiapello and Moulin, 2002). The main features identified by these studies include the continual presence of pollution aerosols associated with fossil-fuel combustion over most of the Northern Atlantic and the transport of Saharan dust across the Atlantic. Measurements over the southern parts of the ocean have been fewer and limited mainly to short cruises between the bordering continental areas.

In this work we present aerosol chemical data measured in November-December 1999 during a cruise over the Atlantic Ocean between the English Channel and the Antarctic coast, along with a corresponding data measured in January 2000 at the Finnish Antarctic research station Aboa $\left(73^{\circ} 03 \mathrm{~S}\right.$, $13^{\circ} 25 \mathrm{~W}, 470 \mathrm{~m}$ a.s.l). The main purpose of the cruise was to transport cargo to several Antarctic research stations. The

Published by Copernicus GmbH on behalf of the European Geosciences Union. 
instruments that were to be used at Aboa were also used during the transport cruise. The main results of the number size distribution measurements associated with these measurements were presented earlier by Koponen et al. (2002, 2003). The chemical composition of coarse particles was presented earlier by Niemi et al. (2005) who analyzed the high-volume samples taken between Europe and Antarctica using scannning electron microscopy coupled with an energy dispersive X-ray microanalyzer (SEM/EDX). Virkkula et al. (2006) presented a detailed analysis of the chemical mass size distributions of various aerosol components. This paper presents the bulk chemical concentrations in one or two size fractions. The data from the Antarctic site are presented only as a last measurement point of the north-south data series.

\section{Methods}

\subsection{Sampling}

Samples for chemical analyses were taken using a highvolume sampler (HV), a virtual impactor (VI) that divides the sample in sub- and supermicron fractions, and a 12-stage small-deposit-area low-pressure impactor (SDI) (Maenhaut et al., 1996). The sampling setup onboard the Akademik Fedorov and at Aboa were described also by Koponen et al. (2002, 2003) and Virkkula et al. (2006). On the ship sample air was taken from $1.5 \mathrm{~m}$ above the bridge and the sample air was led through stainless steel and conductive flexible tubing. The total length of the inlet tubes was $10 \mathrm{~m}$. The tube diameter was $50 \mathrm{~mm}$ for the HV sampler and $25 \mathrm{~mm}$ for the VI and the SDI. Above the bridge there were two positions for the inlets. The inlets were attached on the side railing at the uppermost deck of the ship. Depending on the wind relative direction, the sample was taken from the clean side of the ship or switched off in case of wind from the back of the ship. The HV sampling was continued, however, even when the wind came from the back of the ship. This was because the main reason for taking the HV samples was for the analysis of ${ }^{210} \mathrm{~Pb}$, a tracer for continental air and it is not released by the ship emissions. However, the HV samples were later analyzed for other chemical species as well. One HV sample was contaminated and it was not used for the statistics of species that could be emitted by the ship, such as sulfate, organic and elemental carbon.

The SDI and the VI had a common inlet both on the ship and at Aboa. On the ship the particle diameter for 50\% transmission efficiency $\left(D_{50}\right)$ was approximately $10 \mu \mathrm{m}$. The size distribution analyses (Virkkula et al., 2006) suggest that during strong winds the cutoff was probably lower, approximately $7-8 \mu \mathrm{m}$. At Aboa an inlet with a $D_{50}>20 \mu \mathrm{m}$ was used. The HV had a separate inlet that was used both on the ship and at Aboa. The HV inlet and sample line transmission efficiency was estimated using the equations given by Brock- man (1993). The inlet transmission efficiency depends on wind speed. The average ( \pm standard deviation) wind speed at the inlet was $11 \pm 6 \mathrm{~m} \mathrm{~s}^{-1}$ during the cruise. The respective $D_{50}$ of the combined inlet and sample line was $3.4 \pm 0.5 \mu \mathrm{m}$, taking aspiration and inertial losses in the inlet and sample line losses into account. The $D_{50}$ of the HV sampler was also determined by comparing sodium concentrations measured using both the SDI and the HV. The sodium concentrations analyzed from the multistage impactor were added stage by stage starting from the smallest stage and the average \pm standard deviation diameter where the cumulative concentration equaled the sodium concentration on the HV samples was $3.0 \pm 1.2 \mu \mathrm{m}$. At Aboa the average wind speed was $8 \pm 5 \mathrm{~m} \mathrm{~s}^{-1}$ and the respective $D_{50}$ of the combined HV inlet and sample line was $3.8 \pm 0.4 \mu \mathrm{m}$. On the ship the sample line was two meters inside the laboratory where it got heated due to the temperature difference between the outdoor and laboratory air. Due to the temperature increase relative humidity dropped. There was no heater for the sample line and the heating was not controlled. Temperature and relative humidity of the sample air were monitored at the end of the sample line in the laboratory room. The average relative humidity in the sample line in the laboratory was $40 \pm 15 \%$. At Aboa the inlets were placed $2.5 \mathrm{~m}$ above the container roof which was about $3 \mathrm{~m}$ above the ground. Inside the laboratory container the SDI and VI sample line was $2 \mathrm{~m}$ long and the HV sample line $1 \mathrm{~m}$ long. Both on the ship and at Aboa the main flow 30 LPM of the sample line where the VI and the SDI were attached was produced by the flow to a nephelometer at the end of the sampling line. As on the ship relative humidity dropped due to the temperature difference of the outdoor and indoor air. Temperature and relative humidity of the sample air were monitored at the end of the sample line in the laboratory container. At Aboa the average relative humidity in the sample line in the laboratory was $10 \pm 3 \%$.

The VI flow rate was 16.7 liters $\mathrm{min}^{-1}$ (LPM) and the sampling time $24 \mathrm{~h}$ and $48 \mathrm{~h}$ on the ship and at Aboa, respectively. Teflon (Fluoropore, $47 \mathrm{~mm}, 3 \mu \mathrm{m}$ pore size) was used as filter material both for the fine $\left(D_{p}<1.3 \mu \mathrm{m}\right)$ and coarse $\left(D_{p}>1.3 \mu \mathrm{m}\right)$ size ranges. After sampling the filters were stored in Petri slides and kept in a freezer until the analyses.

The SDI flow rate was 11 LPM. Polycarbonate films (Nuclepore, poreless, $10 \mu \mathrm{m}$ thick) were used as particle impaction substrates. The films were coated with Apiezon L vacuum grease to reduce the bounce-off of particles. The sampling time of the SDI was changed during the cruise. When the ship was in the more polluted part of the cruise a $24 \mathrm{~h}$ sampling time was considered sufficient for collecting samples above the detection limit on all stages. In the cleaner areas the sampling time was doubled to get enough sample material on all stages. The $D_{50}$ values of the SDI stages are $0.045,0.086,0.15,0.23,0.34,0.59,0.80,1.06,1.66,2.68$, 4.08 , and $8.5 \mu \mathrm{m}$. The upper range of the highest stage is determined by the inlet. After sampling the samples were stored in clean vials and kept in a freezer until the analyses. 


\begin{tabular}{|c|c|c|c|c|c|c|c|c|c|c|c|c|c|c|c|c|c|c|}
\hline & & Ac & For & MSA & Pyr & $\mathrm{Cl}$ & $\mathrm{Br}$ & NO3 & Glu & Suc & Mal & $\mathrm{SO} 4$ & Ox & $\mathrm{Na}$ & $\mathrm{NH} 4$ & $\mathrm{~K}$ & $\mathrm{Mg}$ & $\mathrm{Ca}$ \\
\hline \multicolumn{19}{|c|}{ High Volume sampler } \\
\hline \multirow[t]{2}{*}{ Cruise } & ave & 8.8 & 2.49 & 0.00 & 0.00 & 5.58 & 0.00 & 0.91 & 0.00 & 0.00 & 0.00 & 34.0 & 0.00 & 19.9 & 3.1 & 0.00 & 0.05 & 10.0 \\
\hline & std & 2.3 & 0.67 & 0.00 & 0.00 & 4.94 & 0.00 & 0.87 & 0.00 & 0.00 & 0.00 & 16.1 & 0.00 & 1.6 & 1.1 & 0.00 & 0.12 & 4.1 \\
\hline \multirow[t]{2}{*}{ Aboa } & ave & 7.9 & 2.67 & 0.00 & 0.00 & 7.91 & 0.00 & 2.39 & 0.00 & 0.00 & 0.00 & 9.2 & 0.00 & 19.2 & 3.2 & 0.00 & 0.03 & 8.1 \\
\hline & std & 3.0 & 1.05 & 0.00 & 0.00 & 3.30 & 0.00 & 1.62 & 0.00 & 0.00 & 0.00 & 8.6 & 0.00 & 1.3 & 1.5 & 0.00 & 0.14 & 3.4 \\
\hline \multicolumn{19}{|c|}{ Virtual impactor } \\
\hline \multirow[t]{2}{*}{ Cruise } & ave & 2.43 & 1.24 & 0.23 & 0.00 & 3.58 & 0.00 & 5.35 & 0.00 & 0.00 & 0.00 & 1.34 & 0.03 & 4.72 & 0.09 & 0.32 & 0.21 & 3.04 \\
\hline & std & 2.86 & 1.54 & 0.42 & 0.00 & 1.48 & 0.00 & 2.58 & 0.00 & 0.00 & 0.00 & 0.77 & 0.06 & 1.38 & 0.10 & 0.28 & 0.30 & 2.88 \\
\hline \multirow[t]{3}{*}{ Aboa } & ave & 0.00 & 0.00 & 0.00 & 0.00 & 2.32 & 0.00 & 3.15 & 0.00 & 0.00 & 0.00 & 1.73 & 0.06 & 3.56 & 0.00 & 0.32 & 0.00 & 0.78 \\
\hline & std & 0.00 & 0.00 & 0.00 & 0.00 & 0.55 & 0.00 & 1.06 & 0.00 & 0.00 & 0.00 & 0.43 & 0.08 & 0.15 & 0.00 & 0.10 & 0.00 & 0.19 \\
\hline & & & & & & & & SDI & & & & & & & & & & \\
\hline \multirow[t]{2}{*}{ Cruise } & ave & 1.97 & 2.50 & 1.00 & 0.00 & 1.14 & 0.00 & 0.08 & 0.00 & 0.00 & 0.00 & 0.90 & 0.00 & 8.72 & 0.37 & 0.07 & 0.32 & 0.69 \\
\hline & std & 1.27 & 1.49 & 1.22 & 0.00 & 0.88 & 0.00 & 0.26 & 0.00 & 0.00 & 0.00 & 0.77 & 0.00 & 3.86 & 0.28 & 0.29 & 0.54 & 0.81 \\
\hline \multirow[t]{2}{*}{ Aboa } & ave & 0.00 & 0.00 & 0.46 & 0.00 & 0.55 & 0.00 & 0.00 & 0.00 & 0.00 & 0.00 & 0.00 & 0.00 & 5.49 & 0.27 & 0.00 & 0.16 & 0.00 \\
\hline & std & 0.00 & 0.00 & 0.11 & 0.00 & 0.11 & 0.00 & 0.00 & 0.00 & 0.00 & 0.00 & 0.00 & 0.00 & 0.26 & 0.05 & 0.00 & 0.06 & 0.00 \\
\hline
\end{tabular}

\begin{tabular}{lcccccc} 
& & \multicolumn{4}{c}{ HV filters, EC/OC blanks, $\mathrm{ng} \mathrm{m}^{-3}$} \\
& & EC & OC 1 & OC2 & OC3 & OC4 \\
\hline Cruise & ave & 1.9 & 248 & 1.5 & 66 & 14 \\
& std & 5.8 & 89 & 4.9 & 35 & 13 \\
Aboa & ave & 0.0 & 225 & 0.0 & 52 & 22 \\
& std & 3.6 & 64 & 2.7 & 10 & 9 \\
\hline
\end{tabular}

Table 1. Average and standard deviation of concentrations $\left(\mathrm{ng} \mathrm{m}^{-3}\right)$ in the blank filters, calculated using average volume drawn through each sampling system in $24 \mathrm{~h}$.

The HV flow rate was $120 \mathrm{~m}^{3} \mathrm{~h}^{-1}$, the sampling time was $24 \mathrm{~h}$, and the air was sampled on quartz fibre filters (Munktell MK 360, diameter $240 \mathrm{~mm}$ ). The main purpose of the HV samples was to be analyzed for ${ }^{210} \mathrm{~Pb}$. However, the quartz filters were pre-heated at $650^{\circ} \mathrm{C}$ before the campaign in order to make analyses for elemental and organic carbon possible. The HV filters were kept in clean zip-lock bags before and after sampling. After the sampling the filters were deep frozen. The zip-lock bags were made of plastic that may affect the organic carbon analyses. However, this was taken into account by subtracting the average blank concentration from the analyzed organic carbon in the actual samples.

Field blank samples were obtained by loading clean filters in the samplers, keeping them there for $5 \mathrm{~min}$ and packing them exactly like the actual samples. This procedure was done both onboard Akademik Fedorov and at Aboa. There were 28, 9, 5 field blanks for the SDI, VI and HV during the cruise, respectively, and 9, 9, and 4 at Aboa, respectively. For the HV samples the concentrations were analyzed from 3 pieces from each filter sample, as will be explained below, so the HV blank averages were calculated from 15 analyses from the cruise, and the Antarctic average blanks were calculated from 12 analyses.

\subsection{Chemical analyses}

All samples were analyzed for major inorganic and some organic ions using two Dionex-500 ion chromatography systems. Anions were analyzed using an AG11 guard column and an AS11 analytical column with chemical suppression. The eluent for anion analysis was $0.4-30 \mathrm{mM} \mathrm{NaOH}$ solution. Cations were analysed using a CG12A guard column and a CS12A analytical column with electrochemical suppression. The eluent for cation analysis was $25 \mathrm{mM}$ methane- sulphonic acid. The analyzed ions were $\mathrm{Na}^{+}, \mathrm{NH}_{4}^{+}, \mathrm{K}^{+}$, $\mathrm{Mg}^{2+}, \mathrm{Ca}^{2+}, \mathrm{Cl}^{-}, \mathrm{NO}_{3}^{-}, \mathrm{SO}_{4}^{2-}, \mathrm{MSA}^{-}\left(\mathrm{CH}_{3} \mathrm{SO}_{3}^{-}\right)$, oxalate, acetate, succinate, formate, and malonate. Sea salt concentrations were calculated as Sea salt $=\mathrm{Cl}^{-}+1.47 \cdot \mathrm{Na}^{+}$ where 1.47 is the mass ratio of $\left(\mathrm{Na}^{+}+\mathrm{K}^{+}+\mathrm{Mg}^{2+}+\mathrm{Ca}^{2+}\right.$ $+\mathrm{SO}_{4}^{2-}+\mathrm{HCO}_{3}^{-}$) to $\mathrm{Na}^{+}$in sea water (Bates et al.,2001; Quinn et al., 2001). The non-sea-salt concentrations of potassium, magnesium, calcium, and sulfate were calculated from nss $\mathrm{K}^{+}=\mathrm{K}^{+} 0.038 \cdot \mathrm{Na}^{+}$, $\mathrm{nss}^{2+}=\mathrm{Mg}^{2+}-0.12 \cdot \mathrm{Na}^{+}$, nss $\mathrm{Ca}^{2+}=\mathrm{Ca}^{2+} 0.038 \cdot \mathrm{Na}^{+}$and nss $\mathrm{SO}_{4}^{2-}=\mathrm{SO}_{4}^{2-} 0.25 \cdot \mathrm{Na}^{+}$. Sodium was thus used as the sea-salt tracer. Other possible tracers would be $\mathrm{Cl}^{-}$or $\mathrm{Mg}^{2+}$. In atmospheric aerosols chloride is usually depleted due to reactions of sea salt with some acidic compound, such as sulfuric or nitric acid. Therefore chloride is not a suitable tracer. Magnesium would be a good tracer over the ocean but since its concentration in sea salt is about $12 \%$ of the sodium concentration, its absolute concentration is low especially in Antarctic aerosols and relative analytical precision would result in higher uncertainties of nonseasalt concentrations. In the Antarctica the use of sodium as the sea-salt tracer has one disadvantage, though. On the surface of sea ice frost flowers are formed and at temperatures below $-8^{\circ} \mathrm{C}$ sodium sulfate in the frost flowers begins to precipitate out (e.g., Rankin et al., 2002). Wind blowing over the ice may then generate aerosols in which sodium sulfate is depleted compared with sea water. Using sodium as the sea-salt tracer may then result in negative nss sulfate concentrations (e.g., Wagenbach et al., 1998). However, our samples were taken in Antarctic summer and temperatures were mainly above $-8^{\circ} \mathrm{C}$. Further, the mechanism is most likely to take place only in the presence of sea ice surfaces (e.g., Minikin et al., 1998). Therefore this effect is assumed to be negligble in this work. The radioactive noble gas radon-222 


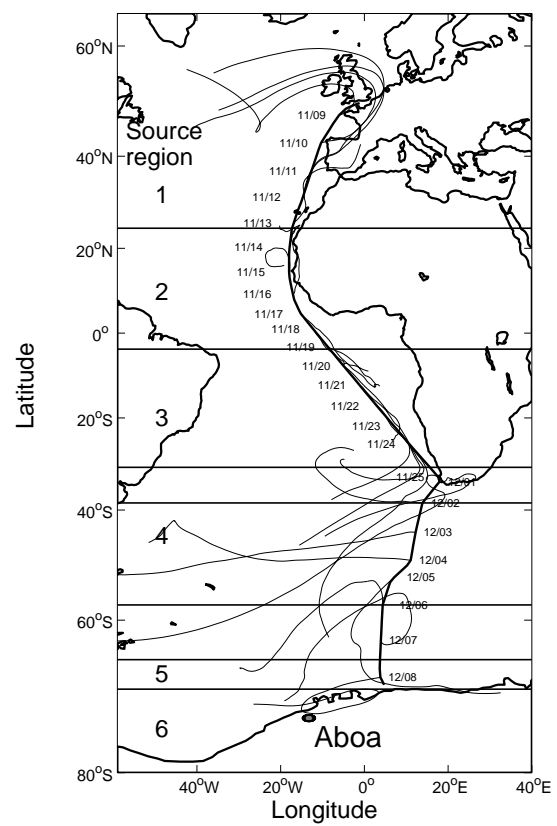

Fig. 1. Ship route, source region limits, and 5-day backtrajectories arriving at $500 \mathrm{~m}$ above sea level.

$\left({ }^{222} \mathrm{Rn}\right)$ emanating from the Earth's crust is often used as a tracer for continental air (e.g., Samuelsson et al., 1986, and references therein). Lead-210 $\left({ }^{210} \mathrm{~Pb}\right)$ is formed in the atmosphere from ${ }^{222} \mathrm{Rn}$ and thus also ${ }^{210} \mathrm{~Pb}$ can be used as a tracer for continental air masses. The exposed HV filters together with field blanks were assayed for ${ }^{210} \mathrm{~Pb}$ with an automatic alpha/beta analyser (Mattsson et al., 1996). The detection limit for ${ }^{210} \mathrm{~Pb}$ depends on the counting time and air volume but is usually about $10 \mu \mathrm{Bq} \mathrm{m}^{-3}$.

The HV filters were first analyzed for ${ }^{210} \mathrm{~Pb}$ activity concentration. After that $1.5 \mathrm{~cm}^{2}$ filter pieces were cut and analyzed for ions using ion chromatography and for elemental and organic carbon (EC and OC) using a thermal-optical analyser (Birch and Cary, 1996). For the analysis of organic carbon the analyzer heats the sample in four consecutive temperature steps that result in organic carbon peaks OC1, OC2, OC3, and OC4. There were no denuders nor a backup filter that could be used to estimate the well-know positive artifact of the OC sampling. It may be assumed that $\mathrm{OC} 1$ consists both of aerosols and adsorbed gaseous organics and that the rest of the OC (OC2-4) is in the aerosol phase (Kirchstetter et al., 2001; Putaud et al., 2000). In order to estimate the particulate organic mass (POM), including $\mathrm{O}$ and $\mathrm{H}$, the OC concentrations obtained from the OC/EC analyzer have to be multiplied by a OC-to-POM conversion factor. In the literature several values have been used for this factor. For instance Hegg et al. (1997) and Putaud et al. (1999) used 1.7 and Turpin and Lim (2001) estimated that the value is 1.6 for urban and 2.1 for nonurban aerosols. Cavalli et al. (2004) used the factor 1.8 for water-soluble organic car- bon and 1.2 for water-insoluble organic carbon. Using FTIR spectroscopy Russell (2003) obtained a mean conversion factor just below 1.4 by analyzing samples taken in northeastern Asia and the Caribbean. In this work 1.4 has been used. POM1, POM2, POM3, POM4, and POM2-4 are the POMs that correspond to $\mathrm{OC} 1, \mathrm{OC} 2, \mathrm{OC} 3, \mathrm{OC} 4$, and $\mathrm{OC} 2-4$. The field blank filters were analyzed for the same species as the samples. The blank atmospheric concentrations presented in Table 1 were calculated by dividing the HV, VI and SDI blank filter concentrations by the volume drawn through the sampler in $24 \mathrm{~h}$ with the flowrates, $120 \mathrm{~m}^{3} \mathrm{~h}^{1}, 16.7 \mathrm{LPM}$, and $11 \mathrm{LPM}$, respectively. For the marine samples the average cruise field blank concentrations and for the Antarctic samples the average Aboa blank concentrations were subtracted from the analyzed concentrations.

Chemical mass apportionment was calculated for the HV samples because only they were analyzed both for the ionic compounds and OC and EC. The chemical mass concentration was calculated by summing the concentrations of nss- $\mathrm{SO}_{4}^{2-}, \mathrm{NH}_{4}^{+}$, nss- $\mathrm{K}^{+}, \mathrm{nss}_{-}-\mathrm{Mg}^{2+}, \mathrm{NO}_{3}^{-}$, sea salt, crustal mass, the analyzed organic ions, EC and POM. Only POM2-4 is used for the mass apportionment. The concentration of crustal mass was calculated from nss-Ca ${ }^{2+} \times\left(1+\Sigma \mathrm{R}_{i}^{\text {crust }}\right) \approx 27.46 \times \mathrm{nss}^{-} \mathrm{Ca}^{2+}$, where $\mathrm{R}_{i}{ }^{\text {crust }}=$ $\mathrm{X}_{i} / \mathrm{Ca}$ is the ratio of concentration of element $\mathrm{X}_{i}$ to Ca concentration in the average crustal composition presented by Mason (1966).

\subsection{Other instruments}

Particle number size distributions $\left(D_{p}=3-800 \mathrm{~nm}\right)$ were measured using a Twin-DMPS system, as described in detail by Koponen et al. (2002, 2003). Black carbon (BC) concentration was measured using an Aethalometer (Magee Scientific, AE-10). The Aethalometer measured only submicron aerosol, there was a preimpactor that removed supermicron particles. Aerosol optical depth (AOD) was measured during cloud-free conditions using a portable Microtops II sunphotometer (Solar Light Co. Inc.).

\subsection{Weather data and backtrajectories}

Data on wind speed and direction, temperature, pressure, and relative humidity were obtained from the ship's weather sensors. At Aboa weather data were obtained from the wind mast placed on the roof of the laboratory container. To analyze transport routes of air masses, backtrajectories were calculated using the NOAA HYSPLIT4 trajectory model (Draxler and Hess, 1997, 1998). The meteorological input data were from the NOAA FNL archives. 


\begin{tabular}{|c|c|c|c|c|}
\hline region & $\begin{array}{l}\mathrm{Dp}<1 \mu \mathrm{m} \\
\text { ave } \pm \text { std }\end{array}$ & $\begin{array}{l}\mathrm{Dp}>1 \mu \mathrm{m} \\
\text { ave } \pm \mathrm{std}\end{array}$ & $\begin{array}{l}\mathrm{Dp}<1 \mu \mathrm{m} \\
\text { ave } \pm \text { std }\end{array}$ & $\begin{array}{l}\mathrm{Dp}>1 \mu \mathrm{m} \\
\text { ave } \pm \text { std }\end{array}$ \\
\hline & \multicolumn{2}{|c|}{ SEA SALT } & \multicolumn{2}{|c|}{ NSS SULFATE } \\
\hline 1 & $275 \pm 128$ & $5366 \pm 1068$ & $1081 \pm 259$ & $60 \pm 106$ \\
\hline 2 & $733 \pm 1405$ & $5585 \pm 1292$ & $1233 \pm 310$ & $226 \pm 288$ \\
\hline 3 & $355 \pm 106$ & $4623 \pm 41$ & $575 \pm 256$ & $6 \pm 39$ \\
\hline 4 & $1131 \pm 288$ & $4681 \pm 329$ & $151 \pm 4$ & $5 \pm 4$ \\
\hline 6 & $30 \pm 16$ & $53 \pm 29$ & $236 \pm 45$ & $18 \pm 6$ \\
\hline & \multicolumn{2}{|c|}{ NITRATE } & \multicolumn{2}{|c|}{ AMMONIUM } \\
\hline 1 & $53 \pm 15$ & $1316 \pm 219$ & $420 \pm 163$ & $4.3 \pm 2.1$ \\
\hline 2 & $19 \pm 17$ & $953 \pm 168$ & $412 \pm 139$ & $27 \pm 31$ \\
\hline 3 & $15 \pm 1$ & $213 \pm 119$ & $63 \pm 39$ & $6.8 \pm 6.4$ \\
\hline 4 & $6 \pm 1.0$ & $14 \pm 4$ & $18 \pm 2$ & $14 \pm 1$ \\
\hline 6 & $1.9 \pm 0.8$ & $7.0 \pm 2$ & $28 \pm 14$ & $1.2 \pm 1$ \\
\hline
\end{tabular}

\begin{tabular}{|c|c|c|c|c|c|c|}
\hline \multicolumn{7}{|c|}{ ORGANIC ANIONS } \\
\hline region & $\begin{array}{l}\mathrm{Dp}<1 \mu \mathrm{m} \\
\text { ave } \pm \text { std }\end{array}$ & $\begin{array}{l}\mathrm{Dp}>1 \mu \mathrm{m} \\
\text { ave } \pm \mathrm{std}\end{array}$ & $\begin{array}{l}\mathrm{Dp}<1 \mu \mathrm{m} \\
\text { ave } \pm \text { std }\end{array}$ & $\begin{array}{l}\mathrm{Dp}>1 \mu \mathrm{m} \\
\text { ave } \pm \text { std }\end{array}$ & $\begin{array}{l}\mathrm{Dp}<1 \mu \mathrm{m} \\
\text { ave } \pm \text { std }\end{array}$ & $\begin{array}{l}\text { Dp }>1 \mu m \\
\text { ave } \pm \text { std }\end{array}$ \\
\hline & \multicolumn{2}{|c|}{ METHANESULFONATE } & \multicolumn{2}{|c|}{ OXALATE } & \multicolumn{2}{|c|}{ ACETATE } \\
\hline 1 & 7.3 & 4.0 & $22 \pm 14$ & $16 \pm 8$ & $5.9 \pm 4.8$ & $26 \pm 10$ \\
\hline 2 & $8.8 \pm 4.4$ & $2.8 \pm 3.2$ & $32 \pm 22$ & $42 \pm 26$ & $2.3 \pm 2.3$ & $31 \pm 32$ \\
\hline 3 & $33 \pm 6$ & $20 \pm 10$ & $3.1 \pm 1.7$ & $7.4 \pm 5.1$ & $4.7 \pm 1.2$ & $15 \pm 5$ \\
\hline 4 & $27 \pm 1$ & $14 \pm 3$ & $0.8 \pm 0.2$ & $1.0 \pm 0.4$ & $7.1 \pm 1.5$ & $11 \pm 1.5$ \\
\hline \multirow[t]{2}{*}{6} & $31 \pm 21$ & $7 \pm 5$ & $0.0 \pm 0.0$ & $2.1 \pm 5.1$ & - & - \\
\hline & \multicolumn{2}{|c|}{ SUCCINATE } & \multicolumn{2}{|c|}{ MALONATE } & \multicolumn{2}{|c|}{ FORMATE } \\
\hline 1 & $1.6 \pm 1.7$ & $1.3 \pm 2.3$ & $2.4 \pm 2.6$ & $9.5 \pm 6.3$ & $10.9 \pm 6.7$ & $18 \pm 7$ \\
\hline 2 & $1.7 \pm 1.9$ & $5.6 \pm 4.7$ & $4.4 \pm 3.7$ & $14.6 \pm 10.1$ & $2.6 \pm 3.4$ & $22 \pm 22$ \\
\hline 3 & - & $0.8 \pm 0.7$ & $1.7 \pm 2.4$ & $4.1 \pm 2.9$ & $1.3 \pm 0.7$ & $13 \pm 5$ \\
\hline 4 & - & - & - & - & $1.1 \pm 0.7$ & $12 \pm 7$ \\
\hline
\end{tabular}

Table 2. Average concentrations of ionic species in submicron and supermicron particles analyzed from the impactor samples in each region. Unit: $\mathrm{ng} \mathrm{m}^{-3}$.

\section{Results and discussion}

\subsection{Overview of the expedition}

The cruise route and associated 5-day backtrajectories were presented by Koponen et al. (2003), Niemi et al. (2005), and Virkkula et al. (2006). The cruise started from Bremerhaven, Germany, but air sampling was started in the English Channel on 8 November 1999. On 25 November the ship arrived at Cape Town from where the cruise continued on 1 December and arrived at the Antarctic coast on 8 December 1999. The instruments were packed and transported to Aboa, where the laboratory was set up and the measurements were continued with the same set of instruments from 6 to 20 January 2000 .

The cruise was divided into five regions according to the location of the ship and back-trajectories calculated using the NOAA HYSPLIT4 model (Draxler and Hess, 1997, 1998) and the meteorological input data from the NOAA FNL archives (Fig. 1). Region 1 (Lat $>24.55^{\circ}$ ) was influenced by European air and region $2\left(24.55^{\circ}>\right.$ Lat $>3.82^{\circ}$, with values $<0$ indicating latitudes in the southern hemisphere) was influenced by Saharan dust and biomass burning (Niemi et al., 2005). In region $3\left(-3.82^{\circ}>\right.$ Lat $\left.>-31.04^{\circ}\right)$ the backtrajectories came from central and southern Africa and from the middle of the Atlantic Ocean. Region $4\left(-38.56^{\circ}>\right.$ Lat $>-$ $57.52^{\circ}$ ) was between Cape Town and the Antarctic pack ice. Region 5 represented pack ice $\left(-66^{\circ}>\right.$ Lat $\left.>-70.10^{\circ}\right)$, even though it consisted only of one sample and thus no statistical conclusions can be drawn. The samples taken at Aboa were classified to region 6 .

3.2 Concentrations and comparisons with other published data

\subsubsection{Ions}

The concentrations of selected ions analyzed from the filter and impactor samples are plotted in Fig. 2. For the SDI the sum of concentrations on each impactor stage and for the VI the sum of fine and coarse filters are shown. For the SDI also the sum of concentrations on stages $1-9$, i.e., of particles with $D_{p}<2.7 \mu \mathrm{m}$ are presented for the comparison with the HV samples. The concentrations of some species are compared with other published data. Ion, elemental and organic carbon concentrations were measured during an oceanographic cruise, Aerosols99, from the US to Cape Town in January-February 1999 (Bates et al., 2001; Quinn et al., 2001). The sub and supermicron data presented by Quinn et al. (2001) were summed for total concentration and plotted as continuous lines in Fig. 2. The latitudes for these data 

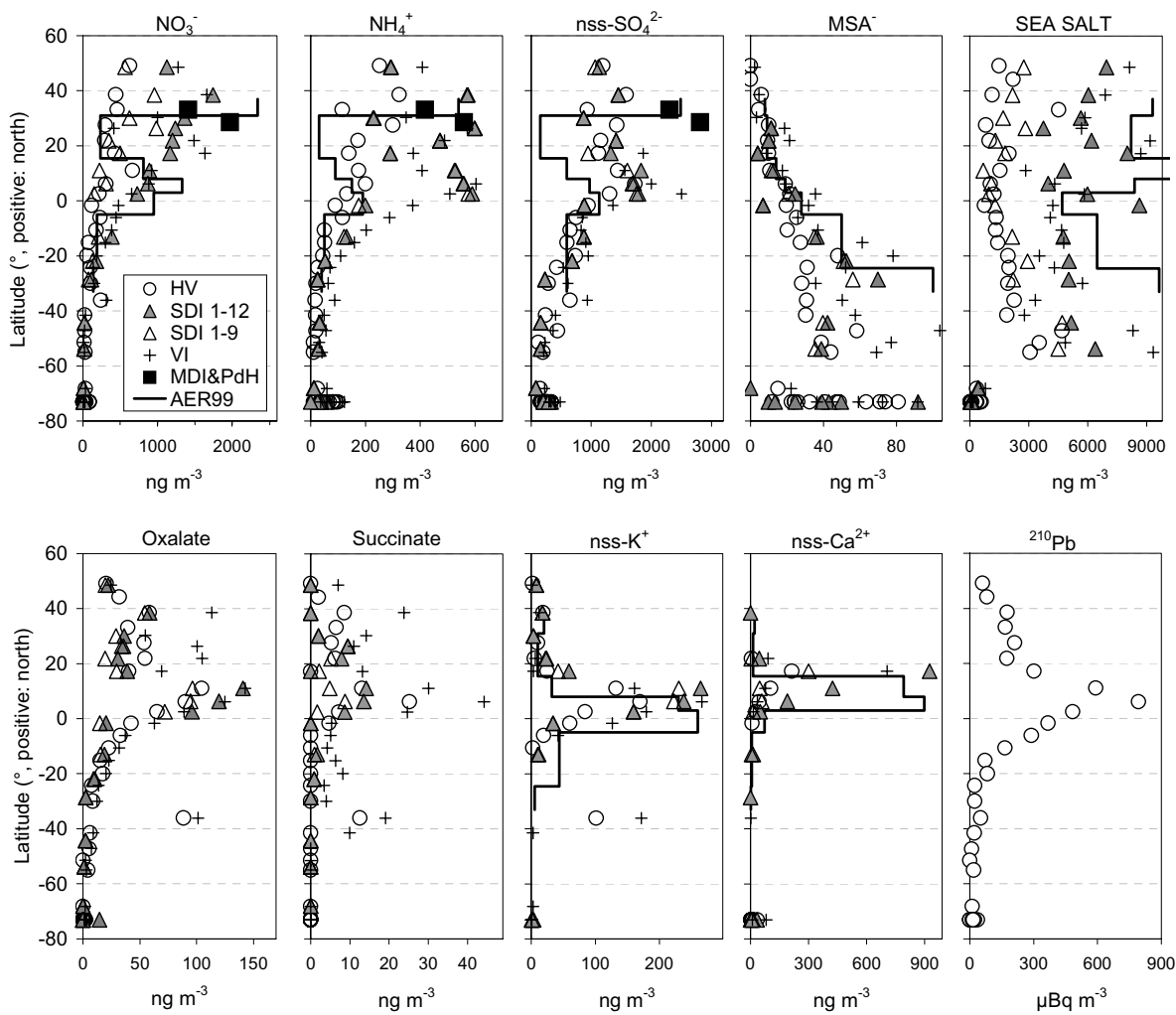

Fig. 2. Selected ion and ${ }^{210} \mathrm{~Pb}$ activity concentrations from north to south during the campaign. The southernmost samples were taken at the Antarctic site Aboa. For the HV the concentrations are for particles with $D_{p}<\sim 3 \mu \mathrm{m}$, for the SDI for particles with $D_{p}$ i 10 $\mu \mathrm{m}$ (SDI 1-12) and for particles with $D_{p}<\sim 2.7 \mu \mathrm{m}$ (SDI 1-9), and for the VI for particles with $D_{p}<\sim 10 \mu \mathrm{m}$. For comparison wintertime average nitrate, ammonium, and nss-sulfate concentrations in polluted air masses measured at Madeira Island (MDI) and Punta del Hidalgo at Tenerife (PdH) are presented (Nuñes, 2002) as well as concentrations measured during Aerosols-99 cruise (Quinn et al., 2001).

are the limits of the meteorological regimes as presented by Quinn et al. (2001). The other comparison data are the average wintertime polluted aerosol concentrations measured at Punta del Hidalgo, Tenerife $(\mathrm{PdH})$ and at Madeira Island (MDI) as part of the LONGTERM subproject of ACE-2. The LONGTERM data is based on high volume samples taken using an inlet with a $10 \mu \mathrm{m}$ cutoff diameter from 1995 to 1998 (Nuñes, 2002).

The VI and SDI were compared by dividing the sum of the two stages of the VI by the sum of the 12 stages of the SDI. For sea-salt the average ratio was $1.0 \pm 0.2$, i.e., in general the two instruments agreed within about $20 \%$. For ions that have gaseous precursors in the atmosphere the ratio varied more, in general so that the concentrations were higher in the VI. Explanations may be that gas-phase precursors reacted with the particles collected on the filter or that evaporation from the low-pressure impactor. The agreement between the $\mathrm{HV}$ and the SDI was best for compounds that exist mainly in small particles, such as nss sulfate. Ammonium exists mainly in the small particles and therefore it is not quite clear why the concentrations in the HV samples were clearly lower than in the other two samplers.
The concentrations of nitrate, ammonium, and nss sulfate decreased almost monotonically from north to south (Fig. 2). In region 1 nitrate and ammonium concentrations were close to the average wintertime polluted aerosol concentrations measured at Tenerife $(\mathrm{PdH})$ and at Madeira (MDI) and also comparable with the North American air mass during Aerosols99. The concentation of nss sulfate was lower. There was a peak in nss sulfate and ammonium concentrations in region 2 close to the North African coast. The maximum concentrations of the ions that contribute less to the total aerosol mass, namely oxalate, malonate, nsspotassium, and nss-calcium, were also observed in the same region, as were also the highest ${ }^{210} \mathrm{~Pb}$ activity concentrations. A small peak of all pollution-related ions was observed in the sample that was started when the ship left Cape Town.

The sea-salt concentrations were in general lower than during Aerosols99 (Quinn et al., 2001) and we never observed concentrations $>9500 \mathrm{ng} \mathrm{m}^{-3}$ although wind speed occasionally exceeded $15 \mathrm{~m} \mathrm{~s}^{-1}$ and whitecaps were present. During high wind speeds on the ocean there are always significant amounts of sea-salt particles with diameter $>10 \mu \mathrm{m}$ (e.g., O'Dowd et al., 1997). These were not sampled due to the inlet cutoff. 

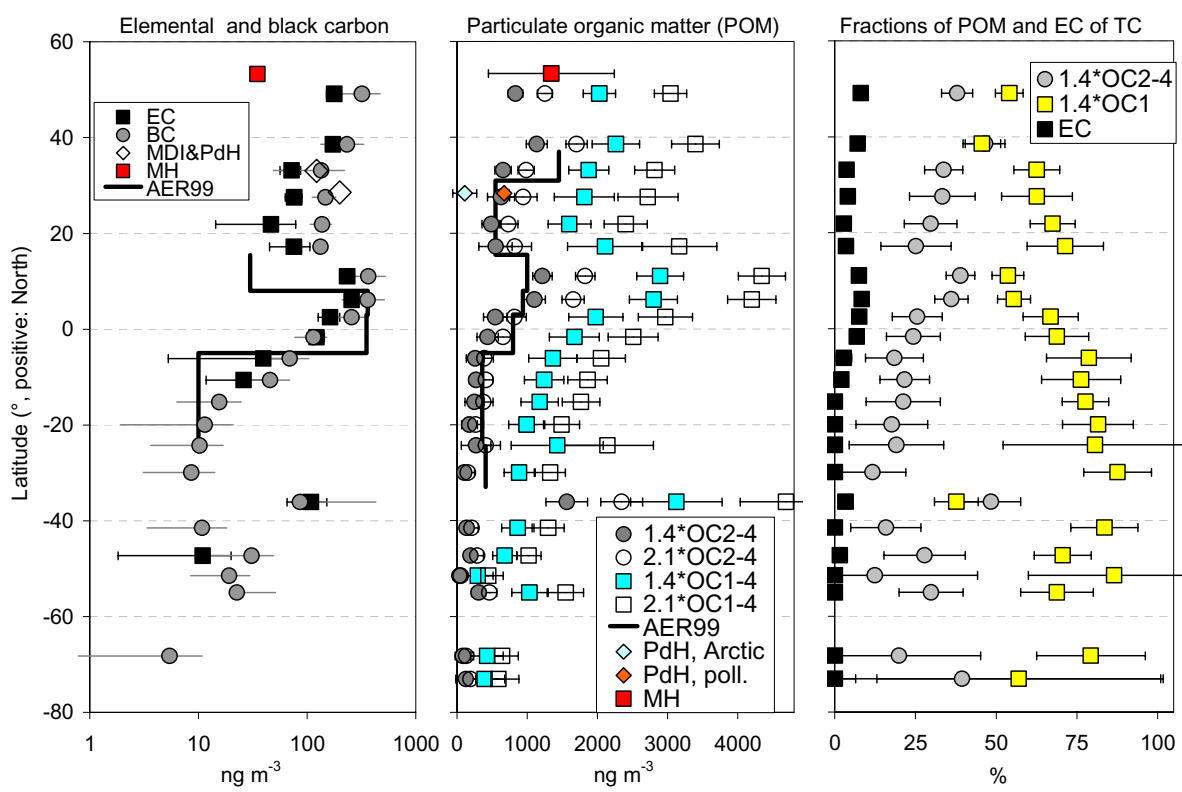

Fig. 3. Black, elemental and organic carbon concentrations and their fractions of the total carbon mass. BC is measured using the Aethalometer, EC and OC from the HV filters using the OC/EC analyzer. To present the sensitivity of POM to POM-to-OC ratio POM concentrations were calculated twice: multiplying the OC concentrations from the OC/EC analyzer by the factor 1.4 and 2.1. OC1-4 is the sum of all organic carbon, OC1 is the carbon that is released during the first heating step and OC2-4 is the sum of carbon released during the heating steps 2 to 4 of the OC/EC analyzer. The OC and EC error bars are calculated from the standard deviation of the concentrations in each piece of the $\mathrm{HV}$ filter plus the standard deviation of the blanks, and the $\mathrm{BC}$ error bars are the standard deviations of the measurements during each filter sampling period. Comparison data: clean air BC and total carbon concentrations at Mace Head (MH) (Cavalli et al., 2004); wintertime BC concentrations in polluted air masses measured at Madeira (MDI) and Punta del Hidalgo at Tenerife (PdH) (Nuñes, 2002); EC and POM concentrations measured during Aerosols99 cruise (AER99) (Quinn et al., 2001); POM concentrations measured at Punta del Hidalgo during flows from the Arctic (PdH, Arctic) and during pollution outbreaks (PdH, poll.) See text for details.

\subsubsection{Organic and elemental carbon}

There was a clear north-south gradient in organic and elemental carbon concentrations (Fig. 3). In region 1 The EC concentrations were comparable with the average wintertime polluted aerosol BC concentrations measured at $\mathrm{PdH}$ and MDI, 199 and $122 \mathrm{ng} \mathrm{m}^{-3}$, respectively (Nuñes, 2002). The EC concentrations measured in the polluted North American air masses during Aerosols99 were below detection limit $10 \mathrm{ng} \mathrm{m}^{-3}$ (Quinn et al., 2001), so this is a clear difference between the polluted air masses coming from $\mathrm{Eu}-$ rope and North America. During our cruise EC concentration decreased to below $10 \mathrm{ng} \mathrm{m}^{-3}$ only south of $20^{\circ} \mathrm{S}$. The aethalometer data $(\mathrm{BC})$ were averaged over the HV sampling periods for comparison with the EC. The BC concentrations were higher than the EC concentrations, linear regression for the samples with $\mathrm{EC}>10 \mathrm{ng} \mathrm{m}^{-3}$ yields $\mathrm{BC}=1.25 \times \mathrm{EC}+29 \mathrm{ng}^{-3}, \mathrm{R}^{2}=0.89$. The difference may to a large extend be attributed to the mass absorption efficiency of $14 \mathrm{~m}^{2} \mathrm{~g}^{-1}$ that was used in the instrument but also to other effects, for instance the response of filter-based absorption methods to scattering aerosols (e.g., Bond et al., 1999). Another important effect is that the Saharan dust particles also absorb light and the aethalometer interprets this as BC.
Organic carbon concentrations are compared with three different measurement campaigns. Quinn et al. (2001) presented submicron and supermicron POM concentrations analysed from samples taken during the Aerosols99 cruise. The samples were taken using a Berner impactor with $\mathrm{Al}$ foils as sampling substrates and analyzed for OC by a thermographic method. The use of an impactor minimizes the positive artifact that is a problem in sampling on quartz filters. On the other hand, in impactors there may be losses due to low pressures. For the organic aerosol mass conversion factor Quinn et al. (2001) used 1.6 for North American air masses and 2.1 for other air mass regions. We have used the factor 1.4 for all samples, as discussed above, but for the comparison in Fig. 3 we have also calculated POM with the factor 2.1. The POM concentrations observed during Aerosols99 were close to those observed in the present work when only POM2-4 is taken into account (Fig. 3). This supports the assumption that the first peak of the evolved gas analysis thermogram represents adsorbed gaseous organics. The other comparison campaign is ACE-2. Submicron aerosol samples taken on quartz filters at Punta del Hidalgo, Tenerife, in summer 1997 were analyzed for OC by evolved gas analysis (EGA) (Putaud et al., 2000). The EGA 
released 4 separate OC peaks as did our method. Putaud et al. (2000) also assumed that OC1 is due to adsorbed gasphase organics but calculated POM using the factor 1.7. In our cruise in regions 1 and 2 the average concentrations of POM (i.e., POM2-4=1.4×OC2-4) were 814 and $723 \mathrm{ng} \mathrm{m}^{-3}$, respectively. These numbers are is in good agreement with the average POM concentrations, $670 \pm 70 \mathrm{ng} \mathrm{m}^{-3}$, observed during ACE-2 at Tenerife during pollution outbreaks from Europe (Putaud et al., 2000).

The third comparison campaign for POM data is that conducted at Mace Head (MH) in 2002 (O'Dowd et al., 2004; Cavalli et al., 2004). Samples were taken with two cascade impactors and analyzed for water-soluble organic carbon (WSOC) and water-insoluble organic carbon (WIOC). Cavalli et al. (2004) used the OC-to-POM conversion factor 1.8 for WSOC and 1.2 for WIOC and presented the average concentrations of WSOC and WIOC for submicron and supermicron size ranges. The sum of the averages of both size ranges was $1343 \mathrm{ng} \mathrm{m}^{-3}$ in all data and approximately $68 \%$ of all OC was in submicron particles. O'Dowd et al. (2004) split the data into the period with low biological activity (LBA) and high biological activity (HBA). The OC concentrations had a very large seasonal variation: in the LBA period, winter, the average total organic carbon concentration was $70 \mathrm{ng} \mathrm{m}^{-3}$ in accumulation mode particles $(0.125 \mu \mathrm{m}<\mathrm{Dp}<0.5 \mu \mathrm{m})$ and $619 \mathrm{ng} \mathrm{m}^{-3}$ in the HBA period. During our cruise the samples from North Atlantic were taken in autumn so the marine biogenic contribution to aerosol was probably low. These samples were taken from air that came from the continents so the organic particles were due to pollution. In region 4, south of Africa, the average POM2-4 was $123 \pm 64 \mathrm{ng} \mathrm{m}^{-3}$. This is much closer to the average concentration $70 \mathrm{ng} \mathrm{m}^{-3}$ in the accumulation mode measured at Mace Head during the period of LBA than to the $619 \mathrm{ng} \mathrm{m}^{-3}$ measured during the period of HBA in North Atlantic (O'Dowd et al., 2004). Our cruise south of Africa took place in early December which is spring in the Southern Ocean. The difference may be due to differences in the biological activity in the oceans at symmetric times of the year. On the other hand, our POM2-4 concentrations in region 4 were close to the average POM concentrations $110 \pm 170 \mathrm{ng} \mathrm{m}^{-3}$ observed at Tenerife during ACE-2 in air masses classified as Arctic (Putaud et al. 2000). The ACE-2 measurements were conducted in summer so there is a clear difference in the concentrations measured at $\mathrm{MH}$ and $\mathrm{PdH}$ as well.

\subsection{Chemical mass apportionment of HV samples}

The non-sea-salt, non-crustal ions dominated the aerosol chemical mass in region 1 and close to the equator (Fig. 4). In the dust plume the crustal mass contributed the most to the aerosol. This is in agreement with the observations of Niemi et al. (2005), who analyzed the elemental composition of individual supermicron particles in the same samples using SEM/EDX method. South of latitude $8^{\circ} \mathrm{S}$ the contribution of sea salt was $>50 \%$, with the exception of the sample started in the Cape Town harbor. In the open ocean south of Cape Town the HV samples the mass fraction of sea salt was $>80 \%$. Over the pack-ice the contribution of the other ions grew again and at the Antarctic site it was higher than that of sea-salt. The reason for that is that Aboa is far from the open ocean and large sea salt particles do not reach it very easily. POM mass fraction was significant in most areas. Only in one sample in region 4 its mass fraction was $\sim 1 \%$, and even in the Antarctic samples it was $\sim 14 \%$. EC mass fraction varied between 1 and $4 \%$ in regions 1 to 3 . In the samples from other regions EC concentrations were below the detection limit so no mass fraction could be calculated.

\subsection{Saharan dust and biomass burning}

During the cruise nss calcium and nss magnesium were observed only in region 2. They are indicators of Saharan dust. The maximum nss calcium and nss magnesium concentrations were observed simultaneously with the maximum AOD, $\sim 0.31$. Nss potassium is also a component of soil dust but it is a also released in biomass burning. When the maximum nss potassium concentration was measured, AOD was slightly lower, 0.27 . The excess-potassiumto-soot ratio is an indicator of the relative contribution of biomass and fossil-fuel burning to soot carbon aerosols, so that ratios larger than about 0.2 can be attributed to biomass burning (Andreae, 1983). Excess potassium is the potassium that is left after subtracting the crustal contribution, i.e., exc $\mathrm{K}^{+}=$nss $\mathrm{K}^{+}-$crustal $\mathrm{K}^{+}=\mathrm{K}^{+}-\left(\mathrm{K}^{+} / \mathrm{Na}^{+}\right)_{\text {seasalt }} \mathrm{Na}^{+}$ - $\left(\mathrm{K}^{+} / \mathrm{Ca}^{2+}\right)_{\text {crustal }} \mathrm{nssCa}^{2+}$. The above formula is based on the assumptions that all sodium is from seasalt and that all nss calcium is crustal. In samples taken in region 2 there may be sodium also in the Saharan dust particles, so the first assumption may lead to underestimation of nss potassium in the clearest Saharan dust samples. Nss calcium may also originate from a biological source, skeletal material from coccolithophore phytoplankton (Artaxo et al., 1992). However, during our cruise nss calcium was observed only in the samples that contained other crustal tracers such as aluminosilicates (Niemi et al., 2005) so the biological contribution to nss calcium may be assumed negligble.

In our samples the average of excess-potassium-to-EC ratio was $0.06,0.27$, and 0.10 in regions 1,2 , and 3 , respectively, and zero within the detection limits in the other regions. The highest ratio 0.94 was observed in the sample started at Cape Town harbor (Fig. 5). In region 2 the highest ratio 0.53 was in the sample that also had the highest EC concentration $\left(256 \mathrm{ng} \mathrm{m}^{-3}\right)$, so this sample may be assumed to be from biomass burning. This sample also had the maximum ${ }^{210} \mathrm{~Pb}$ activity concentration $793 \mu \mathrm{Bq} \mathrm{m}^{-3}$. The plot of excess-potassium-to-soot ratio vs. ${ }^{210} \mathrm{~Pb}$ activity concentration in regions $1-3$ (Fig. 5) suggests that the ${ }^{210} \mathrm{~Pb}$ activity concentration is a good tracer of biomass burning in the 

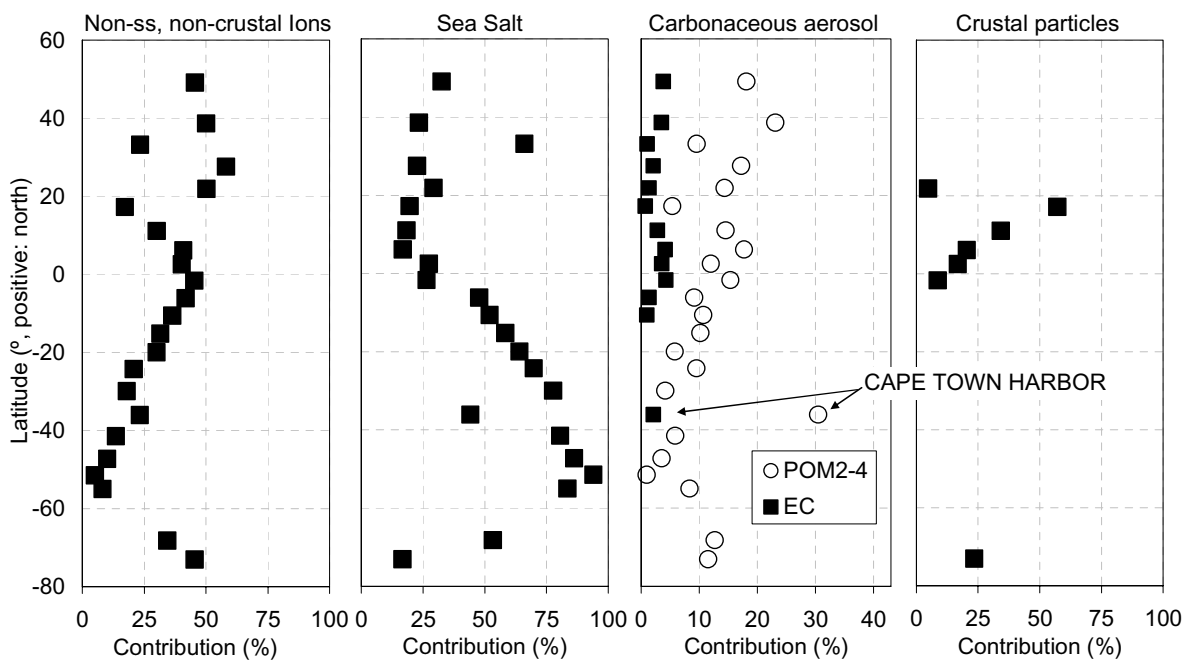

Fig. 4. Contributions of major components to their sum in the $\mathrm{HV}$ samples $\left(D_{p}<3 \mu \mathrm{m}\right)$. Non-sea-salt, noncrustal ions $=\mathrm{nss}_{-} \mathrm{SO}_{4}^{2-}+\mathrm{NH}_{4}^{+}+$ $\mathrm{NO}_{3}^{-}+\mathrm{nssncrK}^{+}+\mathrm{MSA}^{-}+$other organic anions; EC: elemental carbon, POM2-4: organic carbon released from the sample in the EC/OC analyzer temperature steps 2,3 , and 4 , multiplied by the factor 1.4 . Crustal mass $=27.46 \times \mathrm{nss}^{-\mathrm{Ca}^{2+}}$.

African coast. An exception is the sample started at Cape Town harbor where the ratio was high even though the ${ }^{210} \mathrm{~Pb}$ activity concentration was low. A probable explanation is that in the urban area biomass is burned under control in stoves, for instance, which does not lead to significant convection of soil-related particles and gases such as radon and subsequently ${ }^{210} \mathrm{~Pb}$, which takes place when biomass burning is a forest fire. Another mechanism for increased ${ }^{210} \mathrm{~Pb}$ activity concentrations in forest fires is that soil and dust particles deposited on plants get mobilized during forest fires as suggested by Nho et al. (1996).

The best tracer for soil dust in our data is nss calcium. The high correlation of nss potassium with ${ }^{210} \mathrm{~Pb}$ and the low correlation of nss calcium with ${ }^{210} \mathrm{~Pb}$ (Fig. 6) suggests that in our samples the resuspension of soil dust was much less important to ${ }^{210} \mathrm{~Pb}$ emissions than biomass burning. Biomass burning aerosols also contain sulfate, organic and elemental carbon, and other organic species (e.g., Gaudichet et al., 1995; Andreae et al., 1998). This is in agreement with our samples. The aerosol constituents that correlate best with ${ }^{210} \mathrm{~Pb}$ in regions 2 and 3 were nss potassium, EC, POM, oxalate, succinate and formate (Fig. 6).

Figure 6 also shows that in most samples the ratio of the concentration of the analyzed species to ${ }^{210} \mathrm{~Pb}$ activity concentration is higher in region 1 than in regions 2 and 3. For instance, for oxalate the linear regression yields $\mathrm{Ox}=0.22 \times{ }^{210} \mathrm{~Pb}+10 \mathrm{ng} \mathrm{m}^{-3}$ for the samples in region 1 and $\mathrm{Ox}=0.12 \times{ }^{210} \mathrm{~Pb}+8.1 \mathrm{ng} \mathrm{m}^{-3}$ for the samples in regions 2 and 3. Oxalate and nss potassium are both good tracers of biomass burning. However, the ratio of nss potassium to oxalate varies so that it was clearly lower, $0.2 \pm 0.1$, in the air masses from Europe than in region 2 where the clearest African biomass burning aerosols were observed

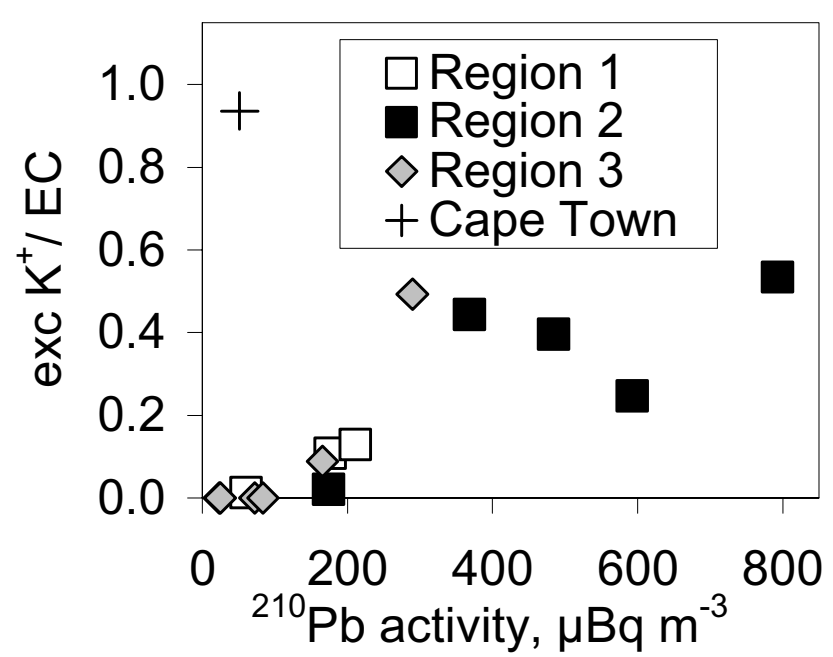

Fig. 5. Excess-potassium-to-soot ratio vs. ${ }^{210} \mathrm{~Pb}$ activity concentration in regions $1-3$ and in the sample started at Cape Town harbor.

(Fig. 7). There the average \pm standard deviation of the ratio was $1.1 \pm 0.5$. Biomass burning is not the only source of oxalate but it is clearly the dominating one. In biomass burning aerosols concentrations may be in the order of several $\mu \mathrm{g} \mathrm{m}^{-3}$ (e.g., Reid et al, 1998) whereas in clean marine aerosols concentrations are some $\mathrm{ng} \mathrm{m}^{-3}$. It is not clear whether they oxalate is emitted directly or produced photochemically in the atmosphere from gaseous precursors (Neusü $\beta$ et al., 2002). The analyses of Falkovich et al. (2005) suggested that the dominating source of oxalate is vegetation combustion and not secondary photochemical processes. 

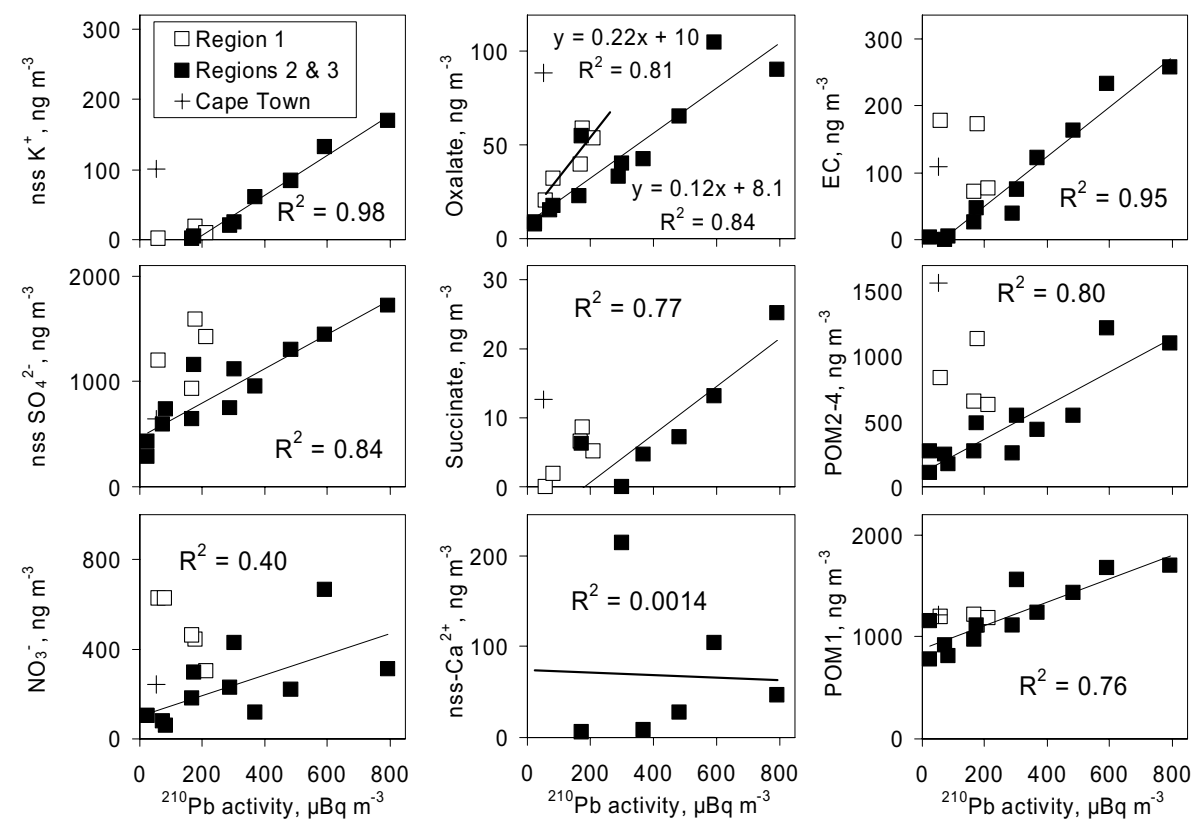

Fig. 6. Major inorganic and selected inorganic ion concentrations, EC, and POM concentrations vs. ${ }^{210} \mathrm{~Pb}$ activity concentration in regions $1-3$ and in the sample started at the Cape Town harbor. The linear regressions were calculated for data in regions $2-3$, for oxalate also for region 1.

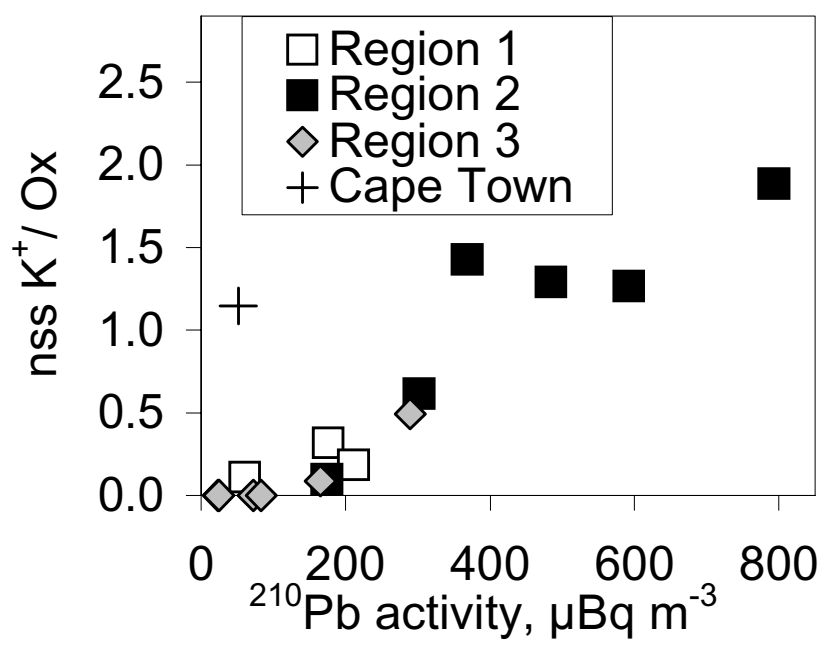

Fig. 7. Nss potassium to oxalate ratio vs. ${ }^{210} \mathrm{~Pb}$ activity concentration in regions 1-3 and in the sample started at the Cape Town harbor.

\subsection{Dilution of continental aerosols over the ocean}

Many of the measured ions, EC, POM, and ${ }^{210} \mathrm{~Pb}$ have their principal or only sources in continental areas. Their concentrations obviously decreased with increasing distance from the continent (Fig. 8). The distance of the ship from the coast was calculated for the ship's locations every $6 \mathrm{~h}$ and averaged over each sampling period. In Fig. 8 also average concentrations between Africa and Antarctica (region 4) are presented to show the marine background concentration level. The mechanisms that lead to decreasing concentrations of these aerosols are dilution with cleaner air, wet and dry deposition, and chemical reactions. Assuming that there is also a marine source $(S)$ of aerosols a simple mass balance equation for the time evolution of the concentrations can be written following Van Dingenen et al. (2000):

$\frac{d C}{d t}=S-\lambda C$

where $\lambda$ is a loss term that includes the different loss mechanisms. If the rate constant $\lambda$ represents the average over the aerosol lifetime the solution becomes

$C(t)=C_{0} e^{-\lambda t}+C_{b g}\left(1-e^{-\lambda t}\right)$

where $C_{0}$ is the concentration at the continent, $C_{b g}=\lambda / S$ is the background marine concentration of the species and $t$ is the time since the air parcel left the continent. Now, since we do not have information on the transport time $t$, we assume that it can be calculated from $t=x / v_{w}$ where $x$ is the distance from the coast and $v_{W}$ the wind speed. It follows that

$C(x)=C_{0} e^{-k x}+C_{b g}\left(1-e^{-k x}\right)$

where $k=\lambda / v_{w}$. If we assume that there is no marine source for aerosols, the concentrations decrease according to

$C(x)=C_{0} e^{-k x}$,

Between latitudes $13^{\circ} \mathrm{N}$ and $13^{\circ} \mathrm{S}$ the concentrations of $\mathrm{EC},{ }^{210} \mathrm{~Pb}$, POM1, POM2-4, nss K ${ }^{+}$, nss $\mathrm{Ca}^{2+}$, nss $\mathrm{SO}_{4}^{2-}$, 

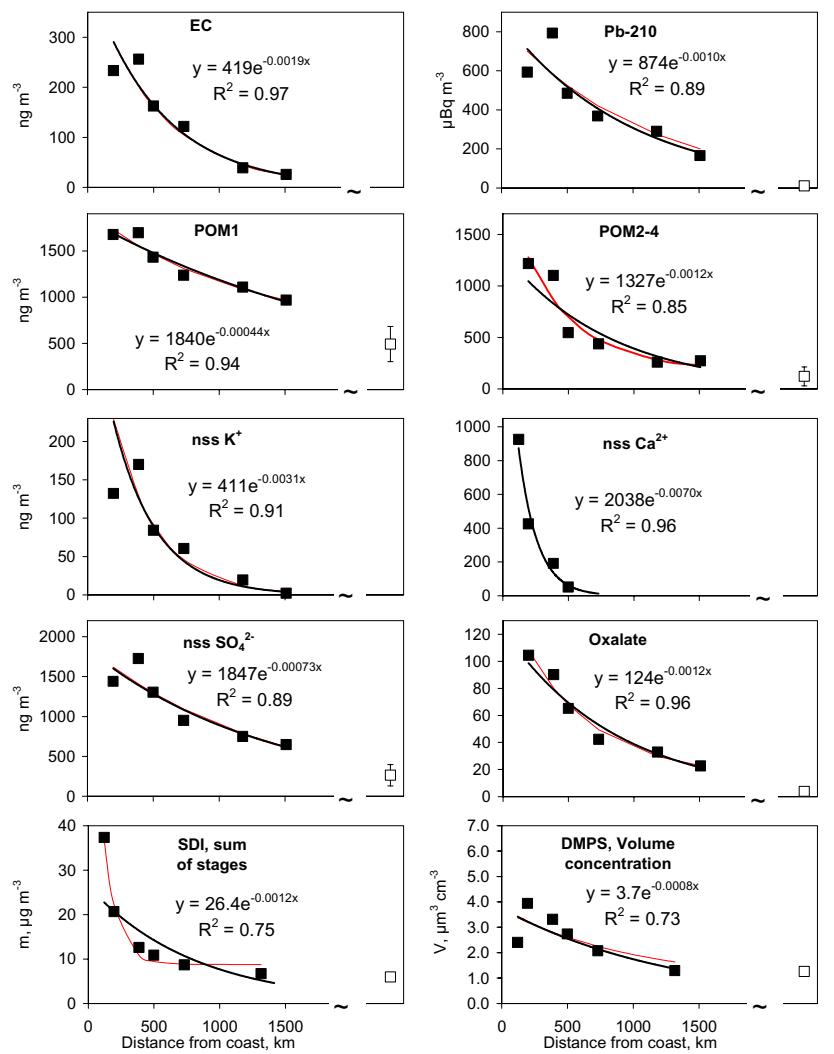

Fig. 8. Concentrations of selected aerosol components as a function of distance from the African coast. The open symbols and the error bars are the average concentrations \pm standard deviations in region 4, between Africa and Antarctica. For EC, nss $\mathrm{K}^{+}$, and nss $\mathrm{Ca}^{2+}$ the concentrations in region 4 were below detection limits so no symbols are given. The black lines, the equations, and the $\mathrm{R}^{2}$ values are the results of the fittings of the data to the function $\mathrm{C}(\mathrm{x})=\mathrm{C}_{0} \exp (-\mathrm{kx})$ and the red lines the fittings of the data to the function $\mathrm{C}(\mathrm{x})=\mathrm{C}_{0} \exp (-\mathrm{kx})+\mathrm{C}_{\mathrm{bg}}(1-\exp (-\mathrm{kx}))$. The data from region 4 were not used for the fittings.

and oxalate all did decrease exponentially with the distance from the African coast (Fig. 8). Using the HV samples $\left(D_{p}<3 \mu \mathrm{m}\right)$ their effective half-value distances, $\mathrm{L}_{1 / 2}=\ln (2) / \mathrm{k}$ (k from the exponential fits in Fig. 8), were $365 \mathrm{~km}, 693 \mathrm{~km}$, $1575 \mathrm{~km}, 578 \mathrm{~km}, 224 \mathrm{~km}, 99 \mathrm{~km}, 950 \mathrm{~km}$, and $578 \mathrm{~km}$, respectively. The fitting was also calculated for the sum of mass concentrations on the SDI stages $\left(D_{p}<10 \mu \mathrm{m}\right)$ and for the volume concentration calculated from the number size distributions measured with the DMPS $\left(D_{p}<0.8 \mu \mathrm{m}\right)$. The SDI mass concentration was calculated by summing the con-

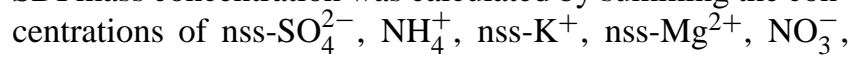
sea salt, crustal mass, and the analyzed organic ions. The exponential decrease did not work so well for the mass concentration sum of the SDI samples. It is obvious in Fig. 8 that the mass concentrations decreased rapidly to a level at $\sim 9 \mu \mathrm{g} \mathrm{m}^{-3}$. Therefore the data in Fig. 8 were fit to function (3) as well. For the SDI stage sum it fits clearly better

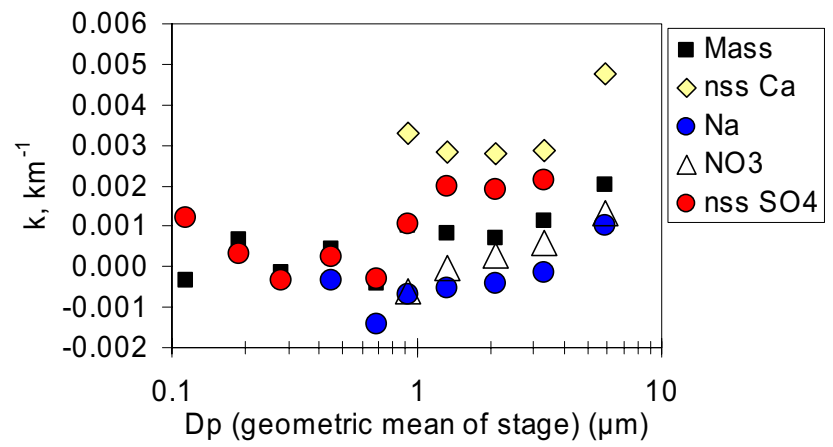

Fig. 9. The size-dependent factor $\mathrm{k}$ from the fitting of the impactor stage data to the function $C(x)=C_{0} \exp (-k x)$. The fitting was done for the same samples that were used for the fitting in Fig. 8.

than the simple decreasing function, yielding the function $\mathrm{C}(\mathrm{SDI}, \mathrm{mass})(\mathrm{x})=99.7 \cdot \exp (0.0097 \cdot)+8.8 \cdot(1-\exp (-0.0097 \cdot))$ in $\mu \mathrm{gm}^{-3}$. The explanation is clear, the main source of aerosol mass concentration in the clean marine areas is sea salt. For the organics the function (3) yielded C(POM1) $(\mathrm{x})=$ $1946 \cdot \exp (-0.0009 \cdot x)+636 \cdot(1-\exp (-0.0009 \cdot x))$ and C(POM2$4)(\mathrm{x})=1952 \cdot \exp (-0.0025 \cdot x)+184 \cdot(1-\exp (-0.0025 \cdot x))$ both in $\mathrm{ng} \mathrm{m}^{-3}$. Both results are in agreement with the marine source of organic aerosols.

All deposition mechanisms are size-dependent so the analysis was also conducted for the impactor stages. The decrease of aerosol mass, nss calcium, sodium, nitrate, and nss sulfate was analyzed by fitting the data to the function $C\left(D_{p}\right)(x)=C_{0}\left(D_{p}\right) \exp \left(-\mathrm{k}\left(\mathrm{D}_{p}\right) \mathrm{x}\right.$. The size-dependent factor $k\left(D_{p}\right)$ from the fitting shows that the rate of decrease was highest for nss calcium (Fig. 9). The decrease of sodium was minimal, only in the highest stage there was a clear decrease, which suggests that most sodium was from sea salt. Nss sulfate decreased in the supermicron stages but not as fast as nss calcium, suggesting that sulfate was also formed by condensation on supermicron soild dust particles during the transport of air masses from the continent. The decrease of nitrate was clearly slower than that of nss sulfate even though nitrate was only present in supermicron particles. This suggests that nitrate was predominantly formed over sea-salt particles rather than over soil dust particles. In the submicron size ranges the concentrations of the analyzed species did not decrease significantly.

3.6 Ionic ratios for assessing the contribution of anthropogenic and natural aerosols

A qualitative estimate of the acidity of aerosols can be given by calculating the measured cation-to-anion ratio in charge equivalents and assuming that the cation deficiency is due to $\mathrm{H}^{+}$ions that cannot be analyzed using ion chromatography. Kerminen et al. (2001) observed that the measured cation-to-anion ratios vary with particle size and sampling site, so that in urban sampling sites the aerosol was 


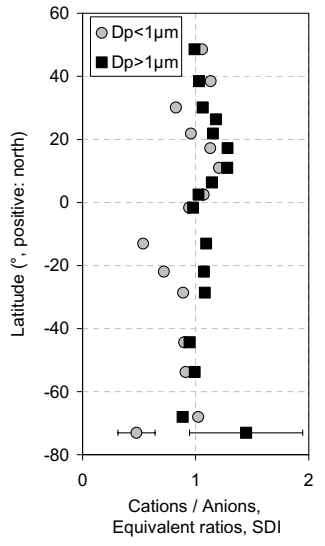

(A)

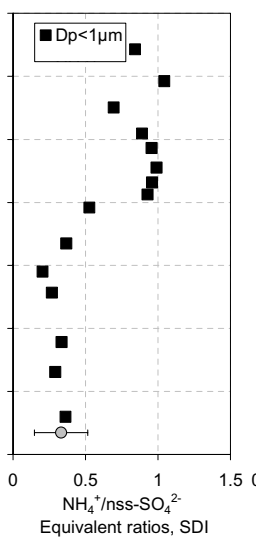

(B)

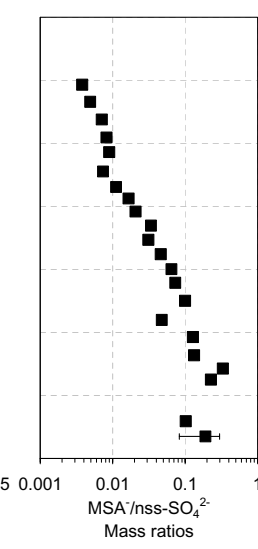

(C)
Fig. 10. Concentration ratios relevant to assessing the contribution of natural and anthropogenic aerosols
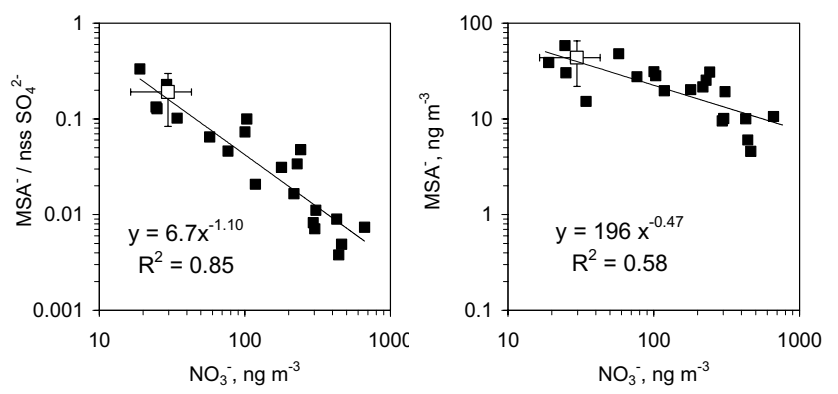

Fig. 11. MSA to nss sulfate ratio and MSA concentration as a function of nitrate concentration in HV samples taken over the ocean (closed squares) and at Aboa (open square). The error bars of the Aboa data point are the standard deviations.

either neutral or alkaline throughout the size spectrum while in background areas the accumulation mode particles were acidic. When using the full chemical mass size distributions our observations were similar (Virkkula et al., 2006). In regions 1 and 2 that are close to the continents with high anthropogenic ion concentrations, the aerosol was close to neutral or alkaline on all impactor stages. In the regions away from the polluted areas the accumulation mode was clearly acidic. However, in this work we divided the particles into submicron and supermicron ranges. For supermicron particles the average cation-to-anion ratio was $1.0 \pm 0.1$ at sea excluding the dust and biomass burning region where the average ratio was $1.2 \pm 0.1$, indicative of alkaline particles (Fig. 10a). At Aboa supermicron aerosols were also alkaline, which is due to the location of the site. Aboa is located on a snow-free nunatak that releases substantial amounts of soil dust during windy conditions. For submicron particles the ion ratio varied more (Fig. 10a). In regions 1 and 2 the ratio was $1.0 \pm 0.1$ and $1.1 \pm 0.1$, respectively, and $0.8 \pm 0.2$ in the other marine regions. At Aboa the ratio was 0.5 \pm 0.1 .
The ammonium to nss sulfate ratio in charge equivalents shows clear differences between the more polluted and less polluted areas (Fig. 10b). In the latter areas the ratio was clearly below one. This ratio gives a more reliable information on the neutralization of submicron aerosol particles than cation-to-anion ratios. Most of ammonium was in submicron particles (Table 2) because the supermicron particles were neutral or alkaline even without ammonium. For ammonia to react with the particles they have to be acidic.

Another indication of the decrease of anthropogenic influence is the MSA to nss sulfate ratio, R, that increased southward (Fig. 10c). The two most important factors contributing to the increase of $\mathrm{R}$ are a decrease of anthropogenic nss-sulfate concentrations and an increase of MSA concentrations. The increase of $\mathrm{R}$ toward higher latitudes latitudes as well as its strong seasonal cycle at high latitudes are wellknown phenomena (e.g., Saltzman et al., 1986; Bates et al., 1992; Ayers et al., 1996, 1997; Heintzenberg et al., 2000; Savoie et al., 2002). The biogenic $\mathrm{R}$ varies from about $0.05-0.06$ in tropical latitudes to values $>0.3$ in high latitudes (Savoie et al., 2002). Using a box model Kerminen et al. (1998) analyzed potential explanations for the increase of R toward high latitudes during the summer: larger MSA yields from DMS oxidation, larger DMSO yields from DMS oxidation followed by the conversion of DMSO to MSA at high latitudes, or lower ambient $\mathrm{H}_{2} \mathrm{O}_{2}$ concentrations at high latitudes leading to less efficient sulfate production in clouds. In our samples taken in the northern hemisphere $\mathrm{R}$ was $<0.01$, so according to the criterium above the nss sulfate in the northern hemisphere was clearly anthropogenic. South of $15^{\circ} \mathrm{S} R$ was $>0.05$. At Aboa $\mathrm{R}$ varied between $\sim 0.04$ and 0.4 .

A way of estimating whether the increase of $R$ southwards is more due to the decrease of anthropogenic sulfate or to the increase of natural MSA is to compare R with a clear indicator of anthropogenic aerosol. The sources of nitrate are mainly anthropogenic so it was used for such a purpose. There was a clear inverse relationship between $\mathrm{R}$ and nitrate concentrations (Fig. 11) and also between MSA and nitrate concentrations. The exponent of the fitted power curves was 1.1 for $\mathrm{R}\left(\mathrm{NO}_{3}^{-}\right)$and -0.47 for $\mathrm{MSA}^{-}\left(\mathrm{NO}_{3}^{-}\right)$(Fig. 11) which means that $\mathrm{R}$ increased clearly faster than MSA with decreasing nitrate concentrations. This suggests that the increase of $\mathrm{R}$ can largely be explained by the decrease of anthropogenic sulfate.

\section{Summary and conclusions}

The concentrations of all anthropogenic aerosol compounds decreased clearly from north to south. An anthropogenic influence was still evident in the middle of the tropical South Atlantic, background values were reached only south of Cape Town. North of the equator $70-80 \%$ of the particles with $\mathrm{D}_{p}<3 \mu \mathrm{m}$ consisted of non-sea-salt species, whereas south 


\begin{tabular}{|c|c|c|c|c|c|c|c|}
\hline region & $\begin{array}{l}\text { POM-1 } \\
\text { ave } \pm \text { std }\end{array}$ & $\begin{array}{l}\text { POM-2 } \\
\text { ave } \pm \text { std }\end{array}$ & $\begin{array}{l}\text { POM-3 } \\
\text { ave } \pm \text { std }\end{array}$ & $\begin{array}{l}\text { POM-4 } \\
\text { ave } \pm \text { std }\end{array}$ & $\begin{array}{l}\text { POM2-4 } \\
\text { ave } \pm \text { std }\end{array}$ & $\begin{array}{c}\text { EC } \\
\text { ave } \pm \text { std }\end{array}$ & $\begin{array}{c}\mathrm{Pb}-210 \text { activity } \\
\text { ave } \pm \text { std } \\
\end{array}$ \\
\hline 1 & $1176 \pm 96$ & $207 \pm 51$ & $218 \pm 28$ & $390 \pm 182$ & $814 \pm 248$ & $125 \pm 99$ & $154 \pm 58$ \\
\hline 2 & $1452 \pm 218$ & $200 \pm 89$ & $211 \pm 57$ & $313 \pm 169$ & $723 \pm 312$ & $149 \pm 77$ & $452 \pm 202$ \\
\hline 3 & $958 \pm 138$ & $65 \pm 28$ & $93 \pm 17$ & $65 \pm 23$ & $223 \pm 63$ & $12 \pm 16$ & $110 \pm 93$ \\
\hline 4 & $492 \pm 191$ & $32 \pm 22$ & $47 \pm 18$ & $44 \pm 35$ & $123 \pm 64$ & $4 \pm 5$ & $10 \pm 9$ \\
\hline 6 & $299 \pm 259$ & $29 \pm 36$ & $41 \pm 21$ & $48 \pm 20$ & $118 \pm 74$ & $2 \pm 2$ & $16 \pm 10$ \\
\hline
\end{tabular}

Table 3. Average concentrations of particulate organic matter (POM), elemental carbon (EC), and ${ }^{210} \mathrm{~Pb}$ activity, analyzed from the $\mathrm{HV}$ filters in each region. Units: $\mathrm{POM}$ and $\mathrm{EC}: \mathrm{ng} \mathrm{m}^{-3},{ }^{210} \mathrm{~Pb}: \mu \mathrm{Bq} \mathrm{m}^{-3}$.

of the equator most of the aerosol mass consisted of sea-salt ions. The contribution of sea salt to the sum of analyzed species of $\mathrm{D}_{p}<3 \mu \mathrm{m}$ particles was $\sim 25 \%$ in the polluted latitudes, $>80 \%$ in the ocean south of Cape Town, $\sim 50 \%$ over the pack-ice region and $<10 \%$ at the Antarctic site Aboa. At Aboa the contribution of sea salt was low because of the $>130 \mathrm{~km}$ distance between the station and the open sea. The contribution of organic carbon was $>10 \%$ in most samples, also at Aboa.

The highest ${ }^{210} \mathrm{~Pb}$ activity concentration coincided with the the highest nss potassium and EC concentrations and not with the highest nss calcium and thus of Saharan dust. This suggests that ${ }^{210} \mathrm{~Pb}$ is a better tracer for biomass burning than for Saharan dust. The most evident explanation is that ${ }^{210} \mathrm{~Pb}$ is attached to the surface of particles and therefore the particles that have the largest surface area have the highest ${ }^{210} \mathrm{~Pb}$ concentrations. This assumption is supported by the fact that there exists an instrument, the epiphaniometer, that measures the aerosol surface area by measuring the decay of ${ }^{211} \mathrm{~Pb}$ attached to the surface of particles (Gäggeler et al., 1989). If ${ }^{211} \mathrm{~Pb}$ successfully attaches to aerosol surfaces then it is a reasonable assumption that ${ }^{210} \mathrm{~Pb}$ will also do so. The size distributions of nss potassium showed that it was predominantly in the small particles (Virkkula et al., 2006). Its integrated surface area was larger than that of nss calcium. In our data the ratio of the two clear tracers of biomass burning, nss potassium and oxalate, was different in European and in African samples, suggesting that this ratio could be used as an indicator of biomass burning type.

There was a very clear inverse exponential relationship between the continental aerosols and the distance of the ship from the African continent. The exponential fits yielded transport distances expressed as half-value distances. The longest half-value distances were for those components that are mainly in the submicron particles and those that have also marine sources. The removal mechanisms are sizedependent. For instance, for dry and wet deposition roughly in the particle size range $>0.1 \mu \mathrm{m}$ the removal rate increases with particle size. This is in agreement with the shortest halfvalue distance, $\sim 100 \mathrm{~km}$, for nss calcium that is mainly a constituent of soil dust particles. The half-value distance of ${ }^{210} \mathrm{~Pb}$ was higher than that of nss potassium, even though their correlation was very high, suggesting that ${ }^{210} \mathrm{~Pb}$ was probably associated with smaller particles than nss potassium. ${ }^{210} \mathrm{~Pb}$ was only determined using $\mathrm{HV}$ samples, so direct comparison of their size distributions cannot be done. For chemical compounds that also have sources in the ocean, for instance nss sulfate, the half-value distances were higher than that of ${ }^{210} \mathrm{~Pb}$.

The acidity of aerosols was estimated by calculating the cation-to-anion ratio in charge equivalents. Supermicron particles were neutral or alkaline in all regions. For submicron particles there were larger differences so that in the polluted regions they were neutral and in the less-polluted regions acidic. However, when the sum of all submicron stages was calculated the acidic nature of the submicron particles over the ocean was not as clear as shown in the size distributions by Virkkula et al. (2006). This is due to the high sea-salt concentration in marine areas and because sea-salt particles exist also in the submicron range. The analysis showed that when data on only two size fractions are available the ammonium to nss sulfate ratio gives a more reliable information on the neutralization of aerosol particles than the cation-to-anion ratio.

The MSA to nss sulfate ratio, $\mathrm{R}$, increased southwards. To assess whether the increase of $\mathrm{R}$ was more due to the decrease of anthropogenic sulfate or to the increase of natural MSA, R was compared with nitrate, a clear indicator of anthropogenic aerosol. There was a very clear inverse relationship between $\mathrm{R}$ and nitrate concentration in our samples. $\mathrm{R}$ increased faster than MSA with decreasing anthropogenic influence which suggests that the $\mathrm{R}$ increase can largely be explained by the decrease of anthropogenic sulfate.

Acknowledgements. The project was funded by the Academy of Finland (Finnish Antarctic Research Program, "Aerosols in Antarctica", contracts no. 43928 and 53669). The Arctic and Antarctic Research Institute (AARI) of St.Petersburg, Russia, is gratefully acknowledged for allowing the measurements onboard $\mathrm{R} / \mathrm{V}$ Akademik Fedorov, as well as the crew of the vessel for fruitful cooperation. The excellent logistical support of FINNARP is also gratefully acknowledged.

Edited by: N. Mihalopoulos 


\section{References}

Andreae, M. O.: Soot carbon and excess fine potassium: long-range transport of combustion-derived aerosols, Sci., 220, 1148-1151, 1983.

Andreae, M. O., Andreae, T. W., Annegarn, H., Beer, J., Cachier, H., le Canut, P., Elbert, W., Maenhaut, W., Salma, I., Wienhold, F.G., and Zenker, T.: Airborne studies of aerosol emissions from savanna fires in southern Africa: 2. Aerosol chemical composition, J. Geophys. Res., 103, 32 119-32 128, 1998.

Gaudichet, A., Echalar, F., Chatenet, B., Quisefit, J. P., Malingre, G., Cachier, H., Buat-Menard, P., Artaxo, P., and Maenhaut, W.: Trace elements in tropical African savanna biomass burning aerosols, J. Atmos. Chem., 22, 19-39, 1995.

Artaxo, P., Rabello, M., Maenhaut, W., and van Grieken, R.: Trace Elements and individual particle analysis of atmospheric aerosols over the Weddell Sea, Tellus 44B, 318-334, 1992.

Ayers, G. P., Cainey, J. M., Granek, H., and Leck, C.: Dimethylsulfide oxidation and the ratio of methanesulfonate to non seasalt sulfate in the marine aerosol, J. Atmos. Chem., 25, 307-325, 1996.

Ayers, G. P., Cainey, J. M., Gilett, R. W., Saltzman, E. S., and Hooper, M.: Sulfur dioxide and dimethyl sulfide in marine air at Cape Grim, Tasmania, Tellus, 49B, 292-299, 1997.

Bates, T. S., Calhoun, J. A., and Quinn, P. K.: Variations in the methanesulfonate to sulfate molar ratio in submicrometer marine aerosol particles over the South Pacific Ocean, J. Geophys. Res. 97, 9859-9865, 1992.

Bates, T. S., Quinn, P. K., Coffman, D. J., Johnson, J. E., Miller, T. L., Covert, D. S., Wiedensohler, A., Leinert, S., Nowak, A., and Neusüss, C.: Regional physical and chemical properties of the marine boundary layer aerosol across the Atlantic during Aerosols99: An overview, J. Geophys. Res., 106(D18), $20767-$ $20782,2001$.

Bergstrom, R. W. and Russell, P. B.: Estimation of aerosol direct radiative effects over the mid-latitude North Atlantic from satellite and in situ measurements, Geophys. Res. Lett., 26, 1731-1734, 1999.

Birch, M. E. and Cary, R. A.: Black carbon-based method for monitoring occupational exposures to particulate diesel exhaust, Aerosol Sci. Technol., 25, 221-241, 1996.

Brockman, J. E.: Sampling and Transport of Aerosols, in: Aerosol measurement: principles, techniques, and applications, edited by: Willeke, K. and Baron, P., Van Nostrand Reinhold, New York, 77-111, 1993.

Cavalli, F., Facchini, M. C., Decesari, S., Mircea, M., Embolico, L., Fuzzi, S., Ceburnis, D., Yoon, Y. J., O’Dowd, C., Putaud, J.-P., and Dell'Aqua, A.: Advances in identification of organic matter in marine aerosol, J. Geophys. Res. 109, D24215, doi:10.1029/2004JD005137, 2004.

Chiapello, I. and Moulin, C.: TOMS and METEOSAT satellite records of the variability of Saharan dust transport over the Atlantic during the last two decades (1979-1997), J. Geophys. Res., 29(8), doi:10.1029/2001GL013767, 2002.

Davison, B., Hewitt, C. N., O’Dowd, C., Lowe, J. A., Smith, M. H., Schwikowski, M., Baltensperger, U., and Harrison, R. M.: Dimethyl sulfide, methane sulfonic acida and physicochemical aerosol properties in Atlantic air from the United Kingdom to Halley Bay, J. Geophys. Res., 101, 22 855-22 867, 1996.

Draxler, R. R. and Hess, G. D.: Description of the HYSPLIT4 mod- elling system, NOAA Tech.Memo. ERL ARL-224, 24, Environ. Res. Lab., Boulder, Colo., 1997.

Draxler, R. R. and Hess, G. D.: An overview of the HYSPLIT4 modeling system for trajectories, dispersion and deposition, Aust. Meteorol. Mag., 47, 295-308, 1998.

Falkovich, A. H., Graber, E. R., Schkolnik, G., Rudich, Y., Maenhaut, W., and Artaxo, P.: Low molecular weight organic acids in aerosol particles from Rondônia, Brazil, during the biomassburning, transition and wet periods, Atmos. Chem. Phys., 5, 781797, 2005,

http://www.atmos-chem-phys.net/5/781/2005/.

Gäggeler, H. W., Baltensperger, U., Emmenegger, M., Jost, D. T., Schmidt-Ott, A., Haller, P., and Hofmann, M.: The epiphaniometer, a new device for continuous aerosol monitoring, J. Aerosol Sci., 20, 557, 1989.

Hegg, D. A., Livingston, J., Hobbs, P. V., Novakov, T., and Russell, P.: Chemical apportionment of aerosol column optical depth off the mid-Atlantic coast of the United States, J. Geophys. Res., 102, 25 293-25 303, 1997.

Heintzenberg, J., Covert, D. S., and Van Dingenen, R.: Size distribution and chemical composition of marine aerosols: compilation and review, Tellus, 52B, 1104-1122, 2000.

Kaufman, Y. J., Tanré, D., and Boucher, O.: A satellite view of aerosols in the climate system, Nature, 419, 215-223, 2002.

Kerminen, V.-M., Hillamo, R. E., and Wexler, A. S.: Model simulations on the variability of particulate MSA to non-sea-salt sulfate ratio in the marine envirnoment, J. Atmos. Chem., 30, 345-370, 1998.

Kerminen, V.-M., Hillamo, R., Teinilä, K., Pakkanen, T., Allegrini, I., and Sparapani, R.: Ion balances of size-resolved tropospheric aerosol samples: implications for the acidity and atmospheric processing of aerosols, Atmos. Environ, 35, 5255-5265, 2001.

Kirchstetter, T. W., Corrigan, C. E., and Novakov, T.: Laboratory and field investigation of the adsorption of gaseous organic compounds onto quartz filters, Atmos. Environ., 35, 1663-1671, 2001.

Koponen, I. K., Virkkula, A., Hillamo, R., Kerminen, V.-M., and Kulmala, M.: Number size distributions and concentrations of marine aerosols: Observations during a cruise between the English Channel and the coast of Antarctica, J. Geophys. Res., 107(D24), 4753, doi:10.1029/2002JD002533, 2002.

Koponen, I. K., Virkkula, A., Hillamo, R., Kerminen, V.M., and Kulmala, M.: Number size distributions and concentrations of the continental summer aerosols in Queen Maud Land, Antarctica, J. Geophys. Res., 108(D18), 4587, doi:10.1029/2003JD003614, 2003.

Leck, C., Heintzenberg, J., and Engardt, M.: A meridional profile of the chemical composition of submicrometre particles over the East Atlantic Ocean: regional and hemispheric variabilities, Tellus 54B, 377-394, 2002.

Lelieveld, J., Crutzen, P. J., Ramanathan, V., Andreae, M. O., Brenninkmeijer, C. A. M., Campos, T., Cass, G. R., Dickerson, R. R., Fischer, H., de Gouw, J. A., Hansel, A., Jefferson, A., Kley, D., de Laat, A. T. J., Lal, S., Lawrence, M. G., Lobert, J. M., MayolBracero, O. L., Mitra, A. P., Novakov, T., Oltmans, S. J., Prather, K. A., Reiner, T., Rodhe, H., Scheeren, H. A., Sikka, D., and Williams, J.: The Indian Ocean experiment: Widespread air pollution from south and southeast Asia, Science, 291, 1031-1036, doi:10.1126/science.1057103, 2001. 
Maenhaut, W., Hillamo, R., Mäkelä, T., Jaffrezo, J.-L., Bergin, M. H., and Davidson, C. I.: A new cascade impactor for aerosol sampling with subsequent PIXE analysis, Nucl. Instrum. Methods Phys. Res. Sect. B 109/110, 482-487, 1996.

Mattsson, R., Paatero, J., and Hatakka, J.: Automatic alpha/beta analyser for air filter samples - absolute determination of radon progeny by pseudo-coincidence techniques, Radiat. Prot. Dosim. 63, 133-139, 1996.

Minikin, A., Legrand, M., Hall, J., Wagenbach, D., Kleefeld, C., Wolff, E., Pasteur, E. C., and Ducroz, F.: Sulfur-containing species (sulfate and methanesulfonate) in coastal Antarctic aerosol and precipitation, J. Geophys Res. 103, 10 975-10990, 1998.

Neusü, C., Gnauk, T., Plewka, A., Herrmann, H., and Quinn, P. K.: Carbonaceous aerosol over the Indian Ocean: OC/EC fractions and selected specifications from size-segregated onboard samples, J. Geophys. Res., 107, D19, 8031, doi:10.1029/2001JD000327, 2002.

Nho, E.-Y., Ardouin, B., Le Cloarec, M. F., and Ramonet, M.: Origins of ${ }^{210}$ Po in the atmosphere at Lamto, Ivory Coast: Biomass burning and Saharan dust, Atmos. Environ. 30, 3705-3714, 1996.

Niemi, J. V., Tervahattu, H., Virkkula, A., Hillamo, R., Teinilä, K., Koponen, I. K., and Kulmala, M.: Continental impact on marine boundary layer coarse particles over the Atlantic Ocean between Europe and Antarctica, Atmos. Res., 75, doi:10.1016/j.atmosres.2005.01.005, 301-321, 2005.

Nuñes, M. J. M.: Establishment of chemical properties of theaerosol in the North East Atlantic Ocean., Ph.D. Thesis, University of Lisbon, 426, 2002.

O'Dowd, C., Smith, M. H., Consterdine, I. E., and Lowe, J. A.: Marine aerosol, sea-salt, and the marine sulphur cycle: A short review, Atmos. Environ., 31, 73-80, 1997.

O’Dowd, C., Facchini, M. C., Cavalli, F., Ceburnis, D., Mircea, M., Decesari, S., Fuzzi, S., Yoon, Y. J., and Putaud, J.-P.: Biogenically driven organic contribution to marine aerosol, Nature, 431, 676-680, 2004.

Prospero, J. M.: Long-term measurements of the transport of African mineral dust to the southeastern United States: Implications for regional air quality, J. Geophys. Res., 104, $15917-$ $15927,1999$.

Putaud, J. P. , Van Dingenen, R., Mangoni, M., Virkkula, A., Raes, F., Maring, H., Prospero, J. M., Swietlicki, E., Berg, O. H., Hillamo, R., and Mäkelä T.: Chemical mass closure and assessment of the origin of the submicron aerosol in the marine boundary layer and the free troposphere at Tenerife during ACE-2, Tellus, 52, 141-168, 2000.

Quinn, P. K., Coffman, D. J., Bates, T. S., Miller, T. L., Johnson, J. E., Voss, K., Welton, E. J., and Neusüss, C.: Dominant aerosol chemical component sand their contribution to extinction during the Aerosols 99 cruise across the Atlantic, J. Geophys. Res., 106(D18), 20 783-20 809, 2001.

Raes, F., Bates, T., McGovern, F., and van Liedekerke, M.: The 2nd aerosol characterization experiment (ACE-2): general overview and main results, Tellus, 52B, 111-125, 2000.

Ramanathan, V., Crutzen, P. J., Kiehl, J. T., and Rosenfeld, D.: Aerosols, climate and the hydrological Cycle, Science, 294, 2119-2124, 2001.
Rankin, A. M., Wolff, E. W., and Seelye, M.: Frost flowers: Implications for tropospheric chemistry and ice core interpretation, J. Geophys. Res., 107(D23), 4683, doi:10.1029/2002JD002492, 2002.

Ravinshankara, A. R.: Heterogeneous and multiphase chemistry in the troposphere, Science, 276, 1058-1065, 1997.

Reid, J. S., Hobbs, P. V., Ferek, R. J., Blake, D. R., Martins, J. V., Dunlap, M. R., and Liousse, C.: Physical, chemical and optical properties of regional hazes dominated by smoke in Brazil, J. Geophys. Res., 103, 32 059-32 080, 1998.

Russell, P. B., Hobbs, P. V., and Stowe, L. L.: Aerosol properties and radiative effects in the United States East Coast haze plume: an overview of the Tropospheric Aerosol Radiative Forcing Observational Experiment (TARFOX), J. Geophys. Res., 104, 2213-2222, 1999.

Russell, L. M.: Aerosol organic-mass-to-organic-carbon ratio measurements, Environ. Sci. Technol. 37, 2982-2987, 2003.

Savoie, D. L., Arimoto, R., Keene, W. C., Prospero, J. M., Duce, R. A., and Galloway, J. N.: Marine biogenic and anthropogenic contributions to non-sea-salt sulfate in the marine boundary layer over the North Atlantic Ocean, J. Geophys. Res., 107, D18, 4356, doi:10.1029/2001JD000970, 2002.

Saltzman, E. S., Savoie, D. L., Prospero, J. M., and Zika, R. G.: Methanesulfonic acid and non-sea-salt sulfate in Pacific air: Regional and seasonal variations, J. Atmos. Chem. 4, 227-240, 1986.

Samuelsson, C., Hallstadius, L., Persson, B., Hedvall, R., Holm, E., and Forkman, B.: ${ }^{222} \mathrm{Rn}$ and ${ }^{210} \mathrm{~Pb}$ in the Arctic summer air, J. Environ.Radioactivity, 3, 35-54, 1986.

Seinfeld, J. H.: Meeting at the interface, Science, 288, 285, 2000.

Sekiguchi, M., Nakajima, T., Suzuki, K., Kawamoto, K., Higurashi, A., Rosenfeld, D, Sano, I., and Mukai, S.: A study of the direct and indirect effects of aerosols using global satellite data sets of aerosol and cloud parameters, J. Geophys. Res.108(D22), 4699, doi:10.1029/2002JD003359, 2003.

Turpin, B. and Lim, H.-J.: Species contributions to PM2.5 mass concentrations: Revisiting common assumptions for estimating organic mass, Aerosol Sci. Technol., 35, 602-610, 2001.

Van Dingenen, R., Raes, F., and Jensen, N. R.: Evidence for anthropogenic impact on number concentration and sulfate content of cloud-processed aerosol particles over the North Atlantic, J. Geophys. Res., 100, 21 057-21 067, 1995.

Van Dingenen, R., Virkkula, A., Raes, F., Bates, T. S., and Wiedensohler, A.: A simple non-linear analytic relationship between aerosol accumulation number and sub-micron volume, explaining their observed ratio in the clean and polluted marine boundary layer, Tellus, 52, 439-451, 2000.

Virkkula, A., Teinilä, K., Hillamo, R., Kerminen, V.-M., Saarikoski, S., Aurela, M., Koponen, I. K., and Kulmala, M.: Chemical size distributions of boundary layer aerosol over the Atlantic Ocean and at an Antarctic site, J. Geophys. Res., 111, D05306, doi:10.1029/2004JD004958, 2006.

Wagenbach, D., Ducroz, F., Mulvaney, R., Keck, L., Minikin, A., Legrand, M., Hall, J. S., and Wolff, E. W.: Sea-salt aerosol in coastal Antarctic regions, J. Geophys Res., 103, 10 961-10974, 1998. 